\title{
REVIVING A NATURAL RIGHT: THE FREEDOM OF AUTONOMY
}

\author{
MiCHAEL ANTHONY LAWRENCE*
}

America in the early twenty-first century is a place where oppressive state constitutional amendments discriminate against millions of gay Americans; where compassionate end-of-life choice is illegal in 49 states and where the one state where it is legal is being sued by the U.S. government; where hundreds of thousands are arrested yearly and tens of thousands are in prison for private possession or use of marijuana and the federal government successfully sues to prevent a state from allowing the use of medical marijuana; where a woman's right to maintain control over her own reproductive decisions hangs by a thread; and where religious freedom is under relentless attack.

Whatever became of the ideal that represented the very foundation of the Founders' and Framers' political theory - 'free[ing] the individual from the oppressive misuse of power, [and] from the tyranny of the state?" How can it be that Tocqueville's warning of a "wholly new species of oppression... [where] the democratic government, acting in response to the will of the majority... create[s] a society with a network of... [rules] that none can escape," has indeed come to pass in modern-day America?

This article explores the historical foundations of the individual right of equality and free choice on matters of natural private concern (collectively, "freedom of autonomy") in America, looks at several present-day applications, and concludes that meaningful steps must be taken - by encouraging greater awareness among lawmakers and courts of original meanings of the constitutional terms "liberty," property," "privileges," and "immunities," and perhaps even through constitutional amendment - to revive this most basic right from an overbearing government. Now is the time for change in America.

* Professor of Law, Michigan State University College of Law. 


\section{INTRODUCTION}

We hold These Truths to be self-evident, that all Men are created equal, that they are endowed by their Creator with certain unalienable Rights, that among these are Life, Liberty, and the Pursuit of Happiness. That to secure these Rights; Governments are instituted among Men, deriving their just Powers from the Consent of the Governed, that whenever any Form of Government becomes destructive of these Ends, it is the Right of the People to alter or to abolish it, and to institute a new Government.

-Declaration of Independence

Something is wrong in twenty-first century America when it comes to recognizing certain "self-evident truths"1 of freedom identified in its founding document nearly 23 decades ago. In particular, the United States today fails to embody the core principle of the Declaration of Independence's core principles of equality and individual liberty. ${ }^{2}$ The quoted words from the Declaration represented more than just an idle, accidental well-turned phrase-as demonstrated by the historical record, they encompassed the very foundation of the Revolutionary political theory, ${ }^{3}$ and were intended to draw strict

1. "We hold these truths to be self-evident ...." THE DECLARATION OF INDEPENDENCE para. 2 (U.S. 1776).

2. THE DECLARATION OF INDEPENDENCE (U.S. 1776). Historian Leonard Levy writes, The pursuit of happiness, a phrase used by Locke for a concept that underlay his political ethics, subsumed the great rights of liberty and property, which were inextricably related. Lockean thought, to which the Framers subscribed, included within the pursuit of happiness that which delighted and contented the mind and a belief that indispensable to it were good health, reputation, and knowledge. There was nothing radical in the idea of the right to the pursuit of happiness. The antiAmerican Tory Dr. Samuel Johnson had used the phrase, and Sir William Blackstone, also a Tory, employed a close equivalent in his Commentaries in 1765 when remarking "that man should pursue his own happiness. This is the foundation of what we call ethics, or natural law."

LEONARD W. LEVY, ORIGINS OF THE BILL OF RIGHTS 251-52 (Yale University Press 1999).

3. Levy writes:

According to American revolutionary theory ... natural rights ... were possessed by individuals in the state of nature, which existed before people voluntarily contracted with each other to establish a government whose purpose was to secure their rights. In the state of nature, when only the law of nature governed, the theory posited that - as the first section of the Virginia Declaration of Rights stated-"all men are by nature equally free and independent, and have certain inherent rights, of which, when they enter into a state of society, they cannot, by any compact, deprive or divest their posterity; namely, the enjoyment of life and liberty, with the means of acquiring and possessing property, and pursuing and obtaining happiness and safety. 
boundaries for the proper reach of government. The radical nature of this statement lies in the fact that no political regime ever before had so clearly and openly placed individual liberties beyond the reach of government.

We have come a long way in America since the founding, but in the modern era we have come in precisely the wrong direction in honoring the sort of rich individual liberties of equality and of free choice on matters of natural private concern (call it collectively "freedom of autonomy") 4 demanded in the Declaration of Independence and memorialized in the Constitution. ${ }^{5}$ Although progress has been made to

LEVY, supra note 2, at 15-16. "Madison, presenting his proposed [Bill of Rights], spoke of "the perfect equality of mankind."' Id. at 254.

4. The term "freedom of autonomy" is derived in part from the Supreme Court's recent Lawrence $v$. Texas decision striking down a state law punishing certain intimate sexual conduct in the home. Writing for the Court in Lawrence, Justice Kennedy announced, "Liberty protects the person from unwarranted government intrusions into a dwelling or other private places.... Freedom extends beyond spatial bounds. Liberty presumes an autonomy of self that includes freedom of thought, belief, expression, and certain intimate conduct." Lawrence v. Texas, 539 U.S. 558, 562 (2003) (emphasis added). In substance, the term "freedom of autonomy" encompasses, but is not completed by, the Supreme Court's Fourteenth Amendment privacy and equal protection doctrines, and is used to allow a fresh look at, and revival of, the thinking that existed during the Revolutionary era of a comprehensive, broad-based individual freedom in which government is strictly subordinate to the individual and acts legitimately only insofar as it protects individual liberty and equality on matters of natural private concern, and to urge a repudiation of the current conventional thinking in which government predominates at the expense of the individual and parses out recognition of individual liberty rights like so many sugar cubes to a cooperative pony.

5. Levy writes:

In the minds of the Framers, many provisions of the Constitution had a libertarian character [of limiting government to promote individual liberty].... During the controversy over ratification of the Constitution, when the omission of a bill of rights was a major issue, many Framers argued, as did Alexander Hamilton in The Federalist, No. 84, "that the Constitution is itself, in every rational sense, and to every useful purpose, a Bill of Rights"... The overwhelming majority of the Convention believed ... that a bill of rights "is unnecessary."

LEVY, supra note 2, at 17-19. In creating a new national government with strictly enumerated limited powers, the Framers could not conceive of the government infringing on rights.

While a new national power system emerged from [the Constitutional ratification] struggle, it does not mark a sudden break in the ideological history or our national origins. [Rather, $t$ ] he essential spirit of eighteenth century reform-its idealism, its determination to free the individual from the power of the state, even a reformed state-lived on, and lives on still.

BERNARD BAILYN, THE IDEOLOGICAL ORIGINS OF THE AMERICAN REVOLUTION viii (Enl. ed 1992 (1967)) (winner of Bancroft and Pulitzer Prizes). Similarly,

[t]o argue that the Framers had used natural rights as a means of escaping obligations of obedience to the king [Declaration] but did not use natural rights "as a source for rules of decision" [Constitution] is hogwash. One has only to read the state recommendations for a bill of rights to know that the natural rights philosophy 
correct some government practices fundamentally inconsistent with the Declaration's exhortations ${ }^{6}$ (slavery was abolished; blacks, women and non-propertied men got the vote; and some (but only some) of the inequities experienced by Native Americans have been addressed), the unfortunate fact remains in the early twenty-first century that-politicians' and others' routine proclamations to the contrary-America, the "Land of the Free" immortalized in story and song, is assuredly no longer "the freest nation on Earth.",

One need look no further than the election of 2004, when state constitutional amendments dramatically restricting the liberties of millions of Americans were passed in all thirteen states where they were on the ballot ${ }^{8}$ - blatant discrimination disguised under the good name of democracy - to get an idea how widespread is the larceny. America is losing ground - is backtracking — on matters of freedom of

seized the minds of the Framers as it had the minds of the rebellious patriots of 1776.

LEVY, supra note 2, at 255.

6. Even in the beginning the statement that "all men are created equal" was hypocritical in the extreme, in light of the facts that: In 1776 slavery was legal - and would continue to be legal for many more decades; that many adults, including women-fully half of the adult population-could not vote; and that Native Americans had only begun to be systematically deprived of their rights. See, e.g., ROBERT A. DAHL, How DEMOCRATIC IS THE AMERICAN CONSTITUTION 124-25 (Yale University Press 2001).

7. Other governments such as The Netherlands, Belgium, and Canada, to name just a few, have surpassed the United States in their tolerance of individual freedom of autonomy. Those who cling to the myth of America as the preeminent keeper of the flame of freedom point mainly to two aspects of the U.S. Constitution. One, the guaranty of a republican form of government requiring representatives to face reelection every few years U.S. CONST. art. IV , § 4; and two, the Bill of Rights' and Fourteenth Amendment's guarantees that certain individual freedoms are beyond the government's reach. As for the first, free democratic elections do not a free nation make. Representatives democratically elected by majorities are all-toocapable of systematically oppressing a vast assortment of minority freedoms, and they do so all the time right here in America.

On the second, there's no question the Bill of Rights and Fourteenth Amendment have been instrumental in protecting individual liberties. The problem is that the guarantees are unevenly applied, in part because the provisions are not explicit in the liberties that they are meant to protect (ambiguity largely by design, of course, to allow future generations some degree of interpretive flexibility to respond to changing times); but also in large part because the U.S. Supreme Court over time has been remarkably unfriendly to the notion of protecting liberty and equality. See generally, e.g., LEVY, supra note 2; AKHIL AMAR, THE BILL OF RIGHTS (Yale University Press 1998); Michael Kent CuRTIS, No STATE Shall ABridge: The FOURTEENTH AMENDMENT AND THE BILL OF RIGHTS (Duke University Press 1986).

8. The amendments were ostensibly to ban same-sex marriage, but in fact their intent and scope are far broader than that in curbing the rights of gay Americans. In Michigan, to offer just one example (this is happening in others of the thirteen states as well), the state's Attorney General recently issued an opinion that state actors could no longer extend benefits to samesex couples. See Glen Staszewski, Avoiding Absurdity, 81 IND. L.J. (forthcoming April 2006). 
autonomy. Today, more than ever, majorities in America are allowed to steal from minorities inherent natural rights of individual autonomy and to impose upon others their own chosen brands of morality and values. ${ }^{9}$

Moreover, even in the areas where America historically has led the way for other nations-protecting religious plurality, for example, as practiced in the pre-Revolutionary colonies ${ }^{10}$ and guaranteed by the Establishment Clause requirement that the government shall not favor one religion over another (or, for that matter, religion in general over non-religion) and the free exercise clause ${ }^{11}$ - Americans' basic freedoms are suffering a slow but steady death by a thousand cuts. ${ }^{12}$

Who can remember the last time Congress took a principled though unpopular stand for individual freedom of autonomy? In the United States Congress of the twenty-first century, the Senate votes 99-0 to condemn a U.S. Court of Appeals decision protecting an atheist's right to have his daughter educated free of government coercion to pledge allegiance to one Nation "under God,"13 and both houses

9. Cartoon philosopher Theodore Dreisel (Dr. Seuss) captures this behavior:

Out west, near Hawtch-Hawtch, there's a Hawtch-Hawtcher Bee-Watcher. His job is to watch ... is to keep both his eyes on the lazy town bee. A bee that is watched will work harder, you see. Well ... he watched and he watched. But, in spite of his watch, that bee didn't work any harder. Not mawtch. So then somebody said, "our old bee-watching man just isn't bee-watching as hard as he can. He ought to be watched by another Hawtch-Hawtcher! The thing that we need is a Bee-WatcherWatcher!" WELL. ...

The Bee-Watcher-Watcher watched the Bee-Watcher. He didn't watch well. So another Hawtch-Hawtcher had to come in as a Watch-Watcher-Watcher! And today all the Hawtchers who live in Hawtch-Hawtch are watching on Watch-WatcherWatchering-Watch, Watch-Watching the Watcher who's watching that bee. You're not a Hawtch-Watcher. You're lucky, you see!

DR. SEUSS, DID I EVER TELL YOU HOW LUCKY YOU ARE? 26-29 (Random House 1973).

10. LEVY, supra note 2, at 6 (writing that "Maryland's Toleration Act of 1649 was far more liberal than England's Toleration Act forty years later... [and] was the first to use the phrase 'the free exercise of religion,' later embodied in the First Amendment. The act also symbolized the extraordinary fact that for most of the seventeenth century in Maryland, Catholics and Protestants openly worshiped as they chose and lived in peace, if not amity... . [T]he Charter of Rhode Island ... made the guarantee of religious liberty a part of the fundamental law.") At the time of the founding, "nowhere did freedom of religion prosper as it did in America." Id. at 3.

11. U.S. Const. amend. I.

12. See infra notes $115-22$ and accompanying text.

13. See Michael Anthony Lawrence, Pledge Ruling Fails to Guard Religious Freedom, THE DETROIT NEWS, June 16, 2004, at A13 (stating, "By failing to make a statement on the issue [of the inclusion of the words " under God" in the pledge of allegiance], the court failed to protect the rights of we the people to be free from a government that would presume to tell 
pass legislation (eagerly signed by the president) attempting through procedural maneuvering to prevent a woman in a persistent vegetative state from exercising her right to be free of unwanted medical treatment and remove feeding tubes, even though state courts had determined repeatedly by the evidentiary standard required by state law (clear and convincing evidence), that she would wish not to be maintained in that condition. ${ }^{14}$

The sorts of positions being taken by Congress and the president in these and other cases ${ }^{15}$ would have been unthinkable through the early years of the nation's history. The most basic concept among the founding generation for what this new nation "America" was to stand for was the lofty principle that government of any sort ${ }^{16}$ simply lacks the authority-legal, moral, or otherwise - to interfere with individual liberty on matters of natural private concern. This principle was important enough over which to fight a war of independence, and is memorialized in word and spirit in the Declaration of Independence and Constitution. It was a major theme of the Reconstruction which brought wayward states into the fold of respecting individual liberty. The preeminence of the concept was recognized by Justice Louis

us whether and how we should practice our faith or religion.").

14. See Carl Hulse \& David D. Kirkpatrick, Congress Passes and Bush Signs Schiavo Measure, NY TIMES, March 21, 2005, at A1; Michael Anthony Lawrence, Actions Show Congress' Total Disregard for a Citizen's "Right to be Left Alone," DETROIT FREE PRESS, March 22,2005 . Congress's action in this case was inappropriate on multiple levels. Indeed, the current House majority leader Tom DeLay epitomizes the constitutionally clueless attitude held by the United States Congress in his comment responding to the federal courts' declining to take up Congress's cause in this case: "[These judges] thumbed their nose at Congress and the president .... [T] he time will come for the men responsible for this to answer for their behavior, but not today." Editorial, Judges under Attack, INTERNATIONAL HERALD-TRIBUNE, April 6,2005 , at 8 . As noted by the editors,

Coming so close to the fatal shooting of one judge in his courtroom and the killing of two family members of another, those words were at best an appalling example of irresponsibility in pursuit of political gain. But they were not an angry, off-thecuff reaction.... Republicans in Congress and the Bush administration, unhappy with some of the rulings of the judiciary, are trying to write it out of its constitutional role.... [I]f Congress succeeds in curtailing the judiciary's ability to act as a check on the other two branches, the United States will be far less free.

Id.

15. The PATRIOT Act of 2001 itself is worthy of volumes of discussion on its abridgement of civil liberties and, for our purposes, freedom of autonomy. Pub. L. No. 108-56, 115 Stat. 272 (2001).

16. "The dominant theory in the United States from the time of the Revolution was that the fundamental law limited all branches of the government, not just the crown as in England, where the great liberty documents did not limit the legislative power." LEVY, supra note 2, at 24. 
Brandeis when he stated famously in 1928, "The makers of our Constitution . . conferred, as against the government, the right to be let alone-the most comprehensive of rights and the right most valued by civilized men." 17

Given the bleak present picture, what does the future hold for the cause of freedom of autonomy in America? Do the results of the 2004 election, as only the most recent example of the atrocities being committed against the cause of individual freedom, suggest that it is too late? Is America incorrigible when it comes to making a real commitment to freedom of autonomy - that is, to respecting the right of other people to do what they will even if it horrifies or repulses us? ${ }^{18}$

17. Olmstead v. United States 277 U.S. 438 (1928) (Brandeis, J., dissenting). The quote, in full, states:

The protection guaranteed by the amendments is much broader in scope. The makers of our Constitution undertook to secure conditions favorable to the pursuit of happiness. They recognized the significance of man's spiritual nature, of his feelings and of his intellect. They knew that only a part of the pain, pleasure and satisfactions of life are to be found in material things. They sought to protect Americans in their beliefs, their thoughts, their emotions and their sensations. They conferred, as against the government, the right to be let alone - the most comprehensive of rights and the right most valued by civilized men. To protect, that right, every unjustifiable intrusion by the government upon the privacy of the individual, whatever the means employed, must be deemed a violation.

$I d$. at 478. As a reminder to Congress, the President, and all other federal, state and local government officials of the axiom that government acts legitimately only insofar as it protects the individual's "right to be let alone," Justice Brandeis' "right to be let alone" opinion should be framed and placed in every federal and state building in the land-perhaps in place of the Ten Commandments.

18. Is there an alternative to a world where groups of individuals and governments "proclaim, in a variety of accents: "We are the Chosen Ones, let the rest of humanity go to hell?" BRUCE ACKERMAN, THE FUTURE OF LIBERAL REVOLUTION 23 (Yale University Press 1992) [hereinafter LIBERAL REVOLUTION]. Yes. On toleration, it is helpful to look at things from a deontological point of view. Individuals and government alike (government is, after all, composed of individual people) presumably would be more tolerant in their behaviors and policies if operating under a semblance of the Rawlsian "veil of ignorance," where we imagine ourselves ignorant of particular facts "such as [our] race, gender, intelligence, disabilities or lack of them, [our] particular life plan and proclivities, and all other particular facts about [our] aspirations and circumstances .... It is like being asked to agree on the rules for playing a game before you know whether they will work to your advantage, or a congressman being bound in advance by the findings of a military base-closing commission before knowing whether the commission will recommend closing the base in his district." IAN SHAPIRO, THE MORAL FOUNDATION OF POLITICS 116 (Yale University Press 2003) (citing JOHN RAWLS, A THEORY OF JUSTICE 113 (The Belknap Press of Harvard University Press (1971)). The idea is rather like the old kindergarten maxim to "treat others as you would like to be treated yourself." In a similar vein, Bruce Ackerman asks us to consider a flesh and blood "stranger":

Strangers may live next door, but they are not like us. They are doing odd things at 
From an institutional sense certainly it is not too late-America has the governmental structure, with the Constitution, to effect major change. And certainly America has the legacy of freedom-the stalwart individuals of the Revolutionary era and Reconstruction had it within themselves to stand firmly on principles of individual liberty and equality. Whether Americans in the twenty-first century have the will to fight the good fight is a much more uncertain question. A good many Americans have proven themselves to be remarkably intolerant on matters involving individual freedom of autonomy-and the necessary changes are going to require a lot of goodwill and tolerance on the part of many millions of people.

Truth be told, America's current struggles are not unanticipated. Alexis de Tocqueville, while predicting the inevitability of democracy's appeal worldwide in stating, "The gradual development of the equality of conditions is ... a providential fact, and it possesses all the characteristics of a Divine decree: it is universal, it is durable, it constantly eludes all human interference, and all events as well as men contribute to its progress," "19 wasn't so sanguine about the longterm effects of democratic political equality on individuals:

[A] wholly new species of oppression will arise. Among citizens equal and alike, the supreme power, the democratic government, acting in response to the will of the majority, will create a society with a network of small complicated rules, minute and uniform, that none can escape. [Sound familiar?] Ultimately, then, the citizens of a democratic country will be reduced to nothing better than a flock of timid and industrious animals, of which the government is the shepherd. ${ }^{20}$

odd times for reasons that disturb us in basic ways. How to respond to this unease? By loving the strangers as ourselves? Only a god could do this: there are too many strangers with too many strangenesses. ... You and I may remain strangers, but we may find common ground in a politics that protects our equal right to cultivate our distinctive characters without any one stranger calling the shots.... If we do this, we may be something more than strangers, if less than friends.... However odd or perverse our beliefs may seem to one another, perhaps we can find common ground in recognizing this: you and I are both struggling to find meaning in the world.

ACKERMAN, supra at 18.

19. DAHL, supra note 6 , at 126 (quoting 1 ALEXIS DE TOCQUEVILLE, DEMOCRACY IN AMERICA . Ixxxi (Henry Reeve, trans., Schocken Books 1961).

20. DAHL, supra note 6, at 133 (paraphrasing closely Tocqueville, supra note 19, at 1: 298, 304, and 2: 380-81). Before Tocqueville, Benjamin Franklin had similar concerns, commenting upon the finished Constitution to the Constitutional Convention (to which he was not a delegate, serving during that time in France) in 1787:

I agree to this Constitution with all its faults, if they are such: because I think a General Government necessary for us, and there is no Form of Government but what 
Tocqueville's prediction provokes a spirited rebuttal from modern defenders of democracy like Ronald Dahl, who states, [I]f we read the passages as a forecast of the way in which democratic countries would tend to evolve, I think we are bound to conclude that Tocqueville was just dead wrong. When we examine the course of democratic development over the past two centuries, and particularly over the century just ended, what we find is a pattern of democratic development that stands in total contradiction to such a prediction. We find instead that as democratic institutions become more deeply rooted in a country, so do fundamental political rights, liberties, and opportunities. As a democratic government matures in a country, the likelihood that it will give way to an authoritarian regime approaches zero. ${ }^{21}$

To the extent Tocqueville's passage is read as predicting that democracy leads inevitably to authoritarian government, Dahl undoubtedly is correct - history has shown, at least to date, that mature democratic regimes do not give rise to authoritarianism. Indeed, democracy is the best political alternative so far devised for protecting individual liberty ${ }^{22}$-post-Enlightenment ${ }^{23}$ or otherwise. But given its more

may be a Blessing to the People if well-administered; and I believe farther that this is likely to well administered for a Course of Years and can only end in Despotism as other Forms have done before it, when the People shall become so corrupted as to need Despotic Government, being incapable of any other.

GORE VIDAL, INVENTING A NATION: WASHINGTON, ADAMS, JEFFERSON 30-31 (Yale University Press 2003). Gore Vidal, the popular author and commentator on American life, offers the following observation: "Now, two centuries and sixteen years later, Franklin's blunt dark prophecy has come true: popular corruption has indeed given birth to that Despotic Government which he foresaw as inevitable at our birth." Id. at 31 .

21. DAHL, supra note 6, at 134 . Dahl adds, "Democracy can, as we all know, collapse into dictatorship. But breakdowns are extraordinarily rare in mature democracies... Even mature democratic countries have had to face wars, economic depression, large-scale unemployment, terrorism, and other challenges. But they did not collapse into authoritarian regimes." Id.

22. SHAPIRO, supra note 18 , at 226 . "The historical record reveals that democracies are better respecters of individual rights and civil liberties than nondemocracies." Moreover, "the democratic tradition also does comparatively well when considered alongside" other postEnlightenment intellectual political traditions like classical utilitarianism, social contract theory, Marxism, and anti-Enlightenment theory. Id. at 227. Specifically:

[c]lassical utilitarianism ... [is] indifferent to individual rights, rendering it vulnerable to Rawls's critique that it fails to take seriously the differences among persons. Neoclassical utilitarianism avoids this charge, but at the price of taking on new difficulties with respect to individual rights. In some formulations it operates with so robust a libertarian conception of individual autonomy that it violates the rights of others once unintended harms and the broader context of resources is taken into account.... The Marxist tradition oscillates between an implausible utopian ideal, according to which the need for rights would be rendered obsolete with the abolition 
natural reading, the passage describes not so much the transformation of government into an authoritarian regime as it does the subtle changes likely to occur after decades and centuries of "majority tyranny" 24 in a democracy. What is the nature of this change? Answer: entrenched bureaucracy, government sclerosis created by generations of majorities seeking to solidify and perpetuate their legacy by institutionalizing their policies through picayune rules and regulations that reach into virtually every corner of life-rules and regulations which by their very nature cannot help but infringe on individual liberties including, for purposes of this essay, the individual freedom of auton-

of injustice, and a strong version of Locke's workmanship ideal. ... Certainly the record of nondemocratic socialist and communist states that have existed in the world is scarcely encouraging [on the matter of protecting individual rights]. ... The anti-Enlightenment move is profoundly unsatisfactory with respect to individual rights. Burke's argument is a caution against making things worse by trying to make them better, and he reasonably reminds us that changing our political institutions has an inescapable dimension of rebuilding a ship at sea. Well taken as his admonitions against vanguardism undoubtedly are, ships sometimes rot and decay, and they can sometimes be improved upon.... [V]arious postmodern and communitarian schools of thought ... may often leave objectionable practices unscathed... . In contrast, the democratic approach creates an impetus to reform inherited practices as they are reproduced into the future .... [and] offers fruitful resources to manage the potential tensions between the Enlightenment commitments to the pursuit of truth through science and the centrality of individual rights.... Both values are better served by the structured instability of power relations that proponents of democracy seek to institutionalize. Democracy is a system in which those who are disadvantaged by present arrangements have both the incentive and the resources to point to the defects of those arrangements, show how the truth about them is being obscured, and try to get those arrangements changed.... It is, however, better thought of as essential medicine for a chronic malady than as a cure that will ever render the treatment redundant.

Id. at 227-30.

23. The Enlightenment's attention to individual rights:

[D] ifferentiates its political philosophy from the ancient and medieval commitments to order and hierarchy. This focus brings the freedom of the individual to the center of arguments about politics. This move was signaled in the natural law tradition by a shift in emphasis from the logic of law to the idea of natural right.

SHAPIRO, supra note 18 , at 14 . Along with its commitment to individual rights, the Enlightenment is characterized by a preoccupation with science. $I d$. at 224 (noting that the concerns of science and individual rights "enjoy a lineage that predates the Enlightenment").

24. James Madison was keenly aware of the threat that majorities pose to individual liberties, stating that:

the Bill of Rights ... [should] limit the powers of government, thus preventing legislative as well as executive abuse, and above all preventing abuses of power by "the body of the people, operating by the majority against the minority." Mere "paper barriers" might fail, but they raised a standard that might educate the majority against acts to which they might be inclined.

LEVY, supra note 2, at 35 . 
omy.

And so it is today. Tocqueville's blunt, remarkably prescient prediction for the mature democracy is an all-too-accurate description of life in twenty-first century America. While it doesn't contribute to a positive self image to consider oneself as part of a flock of timid animals (even if industrious) beholden to its government shepherd, the description rings uncomfortably true. On a more optimistic note, perhaps some among the flock, if given a ray of hope, would enthusiastically agree that the shepherd needs to be re-directed, if not given the crook altogether.

Look again to the inspirational words of the Declaration of Independence, not just as lofty and unattainable rhetoric, but as a realistic-though highly elusive-goal. From the beginning, our forebears knew it would not be easy to "secure these Rights ... . [of] Life, Liberty, and the Pursuit of Happiness." 25 When freedom was on the line, "the colonists knew ... . [w]hat would in fact happen in England and America would be the result .... of the degree of vigilance and the strength of purpose the people could exert. For they believed ... [ $t$ ] he preservation of liberty would continue to be what it had been in the past, a bitter struggle with adversity . ..."26

The preservation of liberty continues to be yet today what it has been in the past - a bitter struggle with adversity. Only time will tell how the next stage in freedom's evolution (or revolution) plays out in America-and whether modern-day Americans have the guts to make the necessary changes to ensure liberty, or instead demonstrate themselves to be mere sheep unworthy of their ancestors' stalwart legacy.

As a preliminary matter, the arguments advanced in this essay might be described at various points, depending on the taxonomy $d u$ jour, ${ }^{27}$ as "rights foundationalist," 28 "liberal,"29 "liberal republican,,30

25. THE DECLARATION OF INDEPENDENCE para. 2 (U.S. 1776).

26. BAILYN, supra note 5, at 85 .

27. Labels, as academics know, can be useful in organizing taxonomies, although they can also be limiting. We've become so committed to roles and labels-and so polarized-in America that we think the roles and labels define us. In the end, it's not the labels-it's the substance behind them-that counts.

28. See 1 BRUCE ACKerman, We the People: Foundations 6-16 (The Belknap Press of Harvard University Press 1991) [hereinafter FOUNDATIONS] (contrasting "monist" arguments (favoring democratic processes over rights theory) with "foundationalist" arguments (those favoring rights theory over democratic processes), and proposing a middle ("dualist") ground).

29. See infra notes $66,70-73$ and accompanying text. 
"Lockean,"31 "Jeffersonian,"32 “constititutionalist,"33 "civil libertar-

30. The arguments line up, at least partially, with Ackerman's description, writing: [t]his kind of liberalism [liberal republicanism], does not look upon people as abstract individuals, divorced from their social contexts, nor does it embrace the notion of "natural rights" to property and contract. ... It insists that the foundation of personal liberty is a certain kind of political life-one requiring the ongoing exertions of a special kind of citizenry. Rather than grounding personal freedom on some putatively prepolitical "state of nature," this kind of liberalism makes the cultivation of liberal citizenship central to its enterprise.

ACKERMAN, FOUNDATIONS, supra note 28, at 30 . Agreed-except there are some rights that are special, that are grounded in a "prepolitical 'state of nature': "privacy" rights, for example, some (but not all) of the rights embraced within the Bill of Rights, such as freedom of speech, freedom of religion, and right to be free of cruel and unusual punishment assuredly are not subject to "ongoing exertions ... of citizenry." Id. They are unalienable natural rights, beyond any actions of the citizenry-nothing the citizenry does or says should be able to alter them. Freedom of autonomy is likewise this sort of absolute natural right.

As outlined by Bernard Bailyn and Leonard Levy in their exhaustive works on the literature of the Revolutionary era, there is an overwhelming abundance of material supporting the point that the post-Revolutionary era did not abandon outright their core belief that certain aspects of individual liberty are beyond the reach of government-state or federal. See BAILYN, supra note 5; LEVY, supra note 2.

31. See, e.g., BAILYN, supra note 5; SHAPIRO, supra note 18. John Locke's theories formed the basis for much of the Revolutionary era's political theory, espoused once again herein. But this essay does not go all the way to the sort of classic liberal:

"Lockean consensus" which trivialize[s] politics and glorifie[s] the natural rights of isolated individuals to life, liberty, and the pursuit of property (or is it happiness?) ... look[s] upon the state as an unmitigated threat to natural liberty ... [believes that t] he government that governs best governs least... [or the Marxist turn that] the only "really important" use of state power is to serve as a revolutionary mechanism for the long march from feudalism to capitalism to socialism.

ACKERMAN, FOUNDATIONS, supra note 28, at 25-26. This essay instead takes the position that effective government plays a vital role in several areas, not the least of which in protecting individual rights like freedom of autonomy. See infra notes 44-45 and accompanying text.

32. The ideal of liberty and individual freedom of autonomy permeate Jefferson's political philosophy.

33. Bruce Ackerman poses an interesting two-stage hypothetical: First, what should be the approach of a Justice of the United States Supreme Court if confronted with a case challenging a validly ratified constitutional amendment establishing Christianity "as the state religion of the American people, and [forbidding] the public worship of other gods?" Should the Justice hold that the amendment is somehow an unconstitutional violation of rights because it acts to repeal the First Amendment's Establishment Clause? The answer is "no"-fidelity to the constitutional process requires that we accept the Constitution's primacy, for better or worse-and an amendment properly proposed and ratified through the Article $V$ process is the highest law of the land which the judiciary must respect. The proper responses for dissenters to such an amendment would be to: (a) work within the system to try to repeal the amendment through the Article V process; or (b) separate/secede. See ACKERMAN, FOUNDATIONS, supra note 28 , at $14-16$.

Second, would it be constitutionally appropriate for the Court to invalidate another validlyratified amendment stating: "Any American advocating the repeal of [the previous Christianity Amendment] is hereby declared guilty of treason and subject to capital punishment upon con- 
ian,"34 "libertarian social democratic,"35 "radical," and/or "revolutionary,"36 - but will settle just for "thought-provoking."

Section II explores progressively the nature of the right of freedom of autonomy, several present-day applications, and the right's historical foundations, and concludes that meaningful steps must be taken to explore and utilize constitutional mechanisms that would assist in reviving this natural right of individual freedom of autonomy on matters of natural private concern as it was envisioned at the time of America's founding and reaffirmed during Reconstruction. Such mechanisms may include, for example, greater judicial respect for the concepts of individual "liberty" and "property" as those terms were originally understood in the Constitution (a greater respect that was, in fact, accorded in the Court's 2003 Lawrence $v$. Texas decision there is hope), ${ }^{37}$ a continuing judicial reinvigoration of the Fourteenth Amendment privileges or immunities clause to its originally intended role, ${ }^{38}$ or best of all (though highly improbable), through constitutional amendment. ${ }^{39}$ The essay closes by asserting that a greater

viction," on the reasoning that it unconstitutionally entrenches the amendment against any subsequent reconsideration by the People under Article V? The committed constitutionalist's answer is again "no" (although it's tempting to say, like Ackerman, that "such questions are best left to the dark day they arise")- - those proposing and ratifying the amendment did so with full knowledge that the amendment would remove the question from any possible further consideration, and they were even still able to mobilize the support specified by Article V to prevail. The constitutional process should be respected. So what is a "liberal," "rights foundationalist," "revolutionary" to do? Answer: As Ackerman says, it might "simply be best for all decent people to quit the regime and struggle to overthrow it[.]" Id. at 16. Agreed-at least with respect to the "quit the regime" part, but perhaps without the "struggle to overthrow it" part; rather, the decent people should seek to separate/secede/divide peacefully without starting a bloody Civil War.

34. The underlying premise of freedom of autonomy is the protection of civil liberty.

35. See infra notes 44,45 .

36. Rights must be protected from majority tyranny through judicial review, and when judicial review is inadequate, through constitutional amendment, and when constitutional amendment is inadequate or impractical, either through stronger conceptions of state independence or perhaps even-if oppression is systematic, persistent, and long-lasting enoughthrough separation or secession. ACKERMAN, FOUNDATIONS, supra note 28, at 16.

37. See supra note 5; infra note 95.

38. See MiCHAEL ANTHONY LAWRENCE, SECOND AMENDMENT INCORPORATION THROUGH THE FourTEENTH AMENDMENT DUE PROCESS ClAUSE (forthcoming 2005).

39. A constitutional amendment would be the ideal mechanism for reviving the natural right of individual freedom of autonomy, since an amendment would give the clearest possible guidance to government on the scope of the right, but ... one must concede that this is little more than a pipe dream. Mobilizing a citizenry to amend the Constitution is no small featthe Constitution has only been amended 18 times over the course of 215-plus years. And let's not fool ourselves. It would be especially difficult to spur Congress to action today, when it is so ideologically polarized, to discuss seriously (much less propose) an amendment that would 
awareness and vigilance by We the People of the natural origins and history of the freedom of autonomy in the founding era is vital if we are to revive this once-prized natural right to a position of prominence in twenty-first century America.

\section{THE FREEDOM OF AUTONOMY}

The premise of this thought-piece is that government in America has fallen far short of the promises made in the Declaration and Bill of Rights, as reinforced by the Fourteenth Amendment, for protecting individual liberties of equality and free choice on matters of natural private concern (collectively "freedom of autonomy")-rights considered throughout the Revolutionary years and at least into the early years of the United States to be natural and virtually inviolable. ${ }^{40}$

The individual right of freedom of autonomy exists in a prepolitical state of nature, having been granted by one's own Creator, before and notwithstanding any attempted interference by false government gods. People individually or collectively may choose to cede their own freedom of autonomy (that too is part of the freedom), but under no circumstances may one person or group of persons (e.g., government) make that decision for another or others against their will. Stated another way, nothing-no person, no government-can take away, against one's will, one's God-given freedom of autonomy. ${ }^{41}$ People individually or collectively may decide to condition

effectively curtail government's ability to regulate on matters involving individual choice and morality-precisely the matters that many representatives' constituents, after all, voted them into office to regulate in the first place. As for mobilizing a majority of states to call for a constitutional convention, the other manner of proposing an amendment under the Article $\mathrm{V}$ process, well . . . even beyond the fact that no amendment has ever been proposed in this manner, one must be skeptical if it could happen for the first time in this instance, given the results of the 2004 election where state constitutional amendments limiting the individual freedom of autonomy of a certain class of people were passed in all eleven states where they were on the ballot. Finally, even if the amendment were somehow miraculously ratified, there is no guarantee the Supreme Court would give it effect. Its recent decision in Lawrence notwithstanding, see infra note 91 , the Court over time has not been especially friendly to liberty -after all, see what it did to the privileges or immunities clause in the Slaughter-House Cases. See, e.g., LAWRENCE, supra note 38.

40. Above all, the Revolutionary ideology "was dominated by a ... cluster of convictions focused on the effort to free the individual from the oppressive misuse of power, from the tyranny of the state." BAILYN, supra note 5 at v-vi. See also infra notes 80-82 and accompanying text.

41. Alexander Hamilton commented that "the sacred rights of mankind are not to be rummaged for among old parchments or musty records. They are written, as with a sunbeam, in the whole volume of human nature, by the hand of the divinity itself, and can never be erased or obscured by mortal power." LEVY, supra, note 2 at 250 (quoting Alexander Hamil- 
their right of freedom of autonomy, as they do when they consent to be governed, in return for certain benefits from the government. To the extent such consent is even possible, ${ }^{42}$ the underlying agreement memorializing the consent between We the People and the government in America-the Constitution-requires that the government must protect our freedom of autonomy from overbearing government and marauding majorities.

Lest one form a mistaken first impression about the broader implications of this "freedom of autonomy as natural right" position, it assuredly does not disparage public service ${ }^{43}$ or advocate a strict libertarian approach that government should have little or no role in all matters $;^{44}$ rather, it suggests that government has an important role, ${ }^{45}$

ton). Another tough-minded American materialist had led the way to such thinking. John Dickinson, speaking of "the rights essential to happiness," rhapsodized: "We claim them from a higher source - from the King of kings, and lord of all the earth. They are not annexed to us by parchment and seals. They are created in us by the decrees of Providence, which establish the laws of our nature. They are born with us; exist with us; and cannot be taken from us by any human power without taking our lives." Id. (quoting John Dickinson). Hence comments like Patrick Henry's to "give me liberty or give me death." Patrick Henry, "Give Me Liberty or Give Me Death." Moses CoIT TYler, AMERICAN STATEMEN: PATRICK Henry, 145 (John T Morse, Jr. ed., Houghton, Mifflin Co., 1887) (1775). ("In short, [these rights] are founded on the immutable maxims of reason and justice. Such opinions were commonplace." LEVY, supra note 2, at 250 (emphasis added)). "So, too, the directly related views expressed by Jefferson in the preamble of the Declaration of Independence reflected commonly held principles. In 1822 John Adams, who had been a member of the committee of Congress that Jefferson had chaired in 1776, observed that there was 'not an idea in it [the Declaration] but what had been hackneyed.' Jefferson asserted that 'all American whigs thought alike' on those matters. The purpose of the Declaration, he wrote, was not 'to find out new principles, or new arguments ... but to place before mankind the common sense of the subject." LEVY, supra note 2, at 250-51 (quoting John Adams).

42. See generally, RANDY BARNETT, RESTORING THE LOST CONSTITUTION 32-52 (Princeton University Press 2004).

43. Under this approach, civic republicanism-the participation of an informed, educated populace in the life of the community-is a virtue.

44. We know too well from experience that human beings left entirely to their own devices are capable of oppression and unspeakable cruelty in the name of God, country, or morality. Paraphrasing the old maxim, those who fail to remember the mistakes of history are bound to repeat them. Idealism or utopianism or nihilism aside, some form of government is necessary - people simply incapable of leaving each other alone.

45. Consistent with the freedom of autonomy position, a fair system of taxation is necessary to support responsible government spending in aiding education, supporting scientific research, providing healthcare for all citizens, administering social security, guaranteeing unemployment benefits, building a strong defense (individual liberty is preserved only so long as the nation is safe from its enemies), and last but not least, providing prompt relief in times of national emergency (a task at which the American federal government demonstrated itself to be woefully inadequate in the wake of Hurricane Katrina in September 2005 in Louisiana and Mississippi). "This conception of governmental power is broad enough to embrace any con- 
but acts legitimately only insofar as it protects the individual's "right to be let alone" as it does so. All government activity must be measured by this test: if the government's action abridges an individual's freedom of autonomy on matters of natural private concern, presumptively it is not legitimate. ${ }^{46}$

To begin, as a matter of methodology, how does one determine (1) what rights are sufficiently "natural" or "fundamental" as to merit protection from government interference; and (2) under what circumstances, if ever, can government abridge a fundamental or natural

ception of the state, from a minimalist, night-watchman state to the contemporary Europeanstyle social welfare state. Whatever version of the state a society chooses to adopt, a government must exist and must possess certain powers that enable the polity collectively to achieve the goals that it sets for itself," James A. Gardner, State Constitutional Rights as Resistance to National Power: Toward a Functional Theory of State Constitutions, 91 GEO. L.J. 1003, 1011 (2003), while at the same time instituting mechanisms to prevent the state from infringing the personal liberties of the polity. The freedom of autonomy position supports the operation of free markets, but also recognizes the important role that government must play to assure a fair game. In its efforts to provide equal economic opportunity, government must not dampen individual initiative or remove legitimate private incentive. If a twenty-first century perspective of the communist experiment-with the implosion and utter failure of the Soviet system, together with the capitalist-in-fact activities of the Chinese-tells us anything, it is that the prospect of private gain is a powerful incentive for enterprise and improved individual economic prospects. There are natural consequences of the market, with winners and losers. That said, government is justified in involving itself in the operation of the free market, for example, to adjust for market failure-where "real world markets fail to conform to ideal models of perfect competition.... The challenge ... is to achieve structural conditions for the legitimate marketplace, not to destroy the genuine freedom that the marketplace makes possible." ACKERMAN, Liberal Revolution, supra note 17, at 9-10.

46. Every tradition attempts in its own way to win political legitimacy. Ian Shapiro summarizes five post-Enlightenment political traditions: utilitarianism, social contract, Marxism, anti-Enlightenment, and democracy. See, generally, SHAPIRO, supra note 18. In the classical utilitarianism tradition, a government's legitimacy is "tied to their willingness and capacity to maximize happiness." SHAPIRO, supra note 18 , at 2 . Legitimacy in the social contract tradition is "rooted in the idea of agreement ... [that is,] consent of the governed, somehow understood [whether by actual agreement, as conceptualized by seventeenth-century social contractarians John Locke and Thomas Hobbes; or by hypothetical agreement, as suggested by twentieth-century theorists like John Rawls] is the source of the state's legitimacy." Id. at 3. In the Marxist tradition a government's legitimacy is tied "to the degree that [it does not] underwrite exploitation and ... to the degree that [it] promote[s] its antithesis, human freedom," Id.at 2; in the anti-Enlightenment tradition "to how well [it] embod[ies] communal values that shape, and give meaning to, the lives of individuals," Id. at 4, where notions of "self" are seen as "rooted in systems of attachment and affiliation that precede and survive individuals." Id., (citing CHARLES TAYLOR, SOURCES OF THE SELF: THE MAKING OF MODERN IDENTITY (Harvard 1989)); and in the democratic tradition, legitimacy exists "when those who are affected by decisions play an appropriate role in making them and when there are meaningful opportunities to oppose the government of the day, replacing it with an alternative." Id. at 5 . Ultimately, of course, the inquiry of whether a government is legitimate begs the seminal questions of "[w]ho is to judge, and by what criteria, whether the laws and actions of states that claim our allegiance measure up?" Id. at 2. 
right?

On the first, we look always to the U.S. Constitution. If the claimed right is not clearly defined therein or is so ambiguous as to lead to uncertainty on whether it is constitutionally protected, then the claimed right does not merit protection. In the best common-law tradition we look to as many sources as possible-historical, philosophical, theoretical, scientific, religious - and do our best through the power of reason to sift and synthesize these sources into animating principles to help us form educated conclusions of whether, pursuant to the Ninth Amendment "unenumerated rights" authority, ${ }^{47}$ the claimed right is sufficiently "fundamental" or "natural" to merit protection under the due process clause or, better yet, under a properlyresurrected Fourteenth Amendment privileges or immunities clause. It's the best we can do, short of a pipeline to the Almighty - a privilege so far as we know nobody has-fundamentalists', governments' and athletes' "God in my corner" claims notwithstanding. Criticisms of this approach as elitist are misplaced (all people, regardless of their station in life, may educate themselves); whereas other criticisms of the approach (relying as it does on judicial review) ${ }^{48}$ as undemocratic are accurate-democracy is simply inadequate alone to protect individual rights, as demonstrated time and again in America.

Applying this approach to our inquiry, the individual right to freedom of autonomy is encompassed within the terms "liberty" 49 and "property" in the Fifth and Fourteenth Amendment due process

47. Madison said that the Ninth Amendment was "meant to guard against the possibility that unenumerated rights might be imperiled by the enumeration of particular rights. By excepting many rights from the grant of powers, no implication was intended, and no inference should be drawn, that rights not excepted from the grant of powers fell within those powers." LEVY, supra note 2, at 247. The rights the Ninth Amendment protected "had to be either 'natural rights' or 'positive rights,' to use the terms Madison employed... [to] distinguish[] 'the preexistent rights of nature' from those 'resulting from a social compact." Id. at 250.

48. Madison wrote, "'independent tribunals of justice will consider themselves in a peculiar manner the guardians of those rights; they will be an impenetrable bulwark against every assumption of power in the legislative or executive, they will be naturally led to resist every encroachment upon rights expressly stipulated for in the constitution." 'LEVY, supra note 2, at 36 (quoting Madison). For his part, "Jefferson believed that an independent court could withstand oppressive majority impulses by holding unconstitutional any acts violating a bill of rights." and wrote to Madison that an advantage of a written bill of rights "was "the legal check which it puts into the hands of the judiciary." Id . at 33 (quoting Jefferson).

49. Freedom of autonomy encompasses, together with the Madison's "perfect equality of mankind," see supra note 3; the "right of privacy" liberty interest recognized by the Supreme Court, see, e.g., Roe v. Wade, 410 U.S. 113 (1973). The Court does not recognize the full scope of freedom of autonomy, however. 
clauses $^{50}$-at least as those terms were originally ${ }^{51}$ understood during the Revolutionary and Reconstruction eras. Leonard Levy reports, for example, that "[i]n the eighteenth century property did not mean merely the ownership of material things. Locke himself had not used the word to denote merely a right to things; he meant a right to rights.... Americans of the founding generation understood property in this general Lockean sense....,52 As James Madison said in 1792, a:

larger and juster meaning [of the term property] ... embraces ... every thing to which a man may attach $a$ value and have $a$ right.... [A] man has property in his opinions and the free communication of them. He has a property of peculiar value in his religious opinions, and in the profession and practices dictated by them. He has property very dear to him in the safety and liberty of his person. He has an equal property in the free use of his faculties and free choice of the objects on which to employ them. In a word, as a man is said to have a right to his property, he may be equally said to have a property in his rights. ${ }^{53}$

Under the Lockean and Madisonian terms, then, a proper definition of "property" would include two aspects: (i) a right to material "things"; and (ii) a right to non-material "thing[s] to which a man may attach a value and have a right." The first "material" aspect of property has long been recognized by the judiciary under several constitutional provisions, ${ }^{54}$ the combination of which have been effective in

50. "[N]or be deprived of life, liberty or property, without due process of law," U.S. CONST. amend. V; "nor shall any State deprive any person of life, liberty or property, without due process of law." U.S. CONST. amend. XIV, $\S 1$.

51. We don't join the "originalism" versus "non-originalism" discussion right now, except to say that for our purposes it is vitally important to understand the original intent and meaning of the framers on concepts of "liberty," "property," and "privileges or immunities," because our very consent to be governed under the Constitution's terms was based upon the meanings of the terms at the time of ratification. The only way we can know if the government is upholding its end of the bargain is if we know what the bargain was in the first place.

52. Levy, supra note 2, at 252. Locke asserted, "[People] unite[] for the general preservation of their lives, liberties, and estates, which I call by the general name - property.... [B]y property I must be understood here as in other places to mean that property which men have in their persons as well as goods." Id. at 252-53 (quoting JOHN LOCKE, SECOND TREATISE ON GOVERNMENT (Peter Laslett ed., Cambridge University Press 1988)). Levy notes, "[a]t least four times in his Second Treatise, Locke used the word property to mean all that belongs to a person, especially the rights he wished to preserve." Id.

53. LEVY, supra note 2, at 252 (emphasis added) (quoting James Madison). This broad view was the Reconstruction interpretation as well. See infra notes 178-79 and accompanying text.

54. Specifically, material property is protected by the Fifth Amendment takings clause (the Court has developed a rich takings clause jurisprudence in which the judiciary will find 
protecting individuals' material property from an overreaching government.

As for the "non-material" aspect of property, looking again at Madison's description of property we see that all of the examples he lists as constituting property are freedom of autonomy rights-i.e, all are liberties involving an individual's rights of equality and freedom of choice on matters of natural private concern. Of those, most, but not all, are adequately protected elsewhere in the Constitution: "opinions and free communication" are explicitly protected by the First Amendment (free speech clause), as are "religious opinions, and ... the[ir] profession and practices" (free exercise clause); "safety and liberty of his person" are also explicitly protected by, for example, the eighth amendment (cruel and unusual punishment, excessive bail clauses), and by the Art. I, section 9 right of writ of habeas corpus. ${ }^{55}$ Only "free use of his faculties and free choice of the objects on which to employ them" — classic "freedom of autonomy" rights-are nowhere else explicitly protected in the constitution-and the fact is courts have never protected this form of property, so "we have lost [it]." This is why ideally we need (even if in practical terms we cannot get) a constitutional amendment to protect freedom of autonomy. ${ }^{58}$

Continuing with our inquiry, since freedom of autonomy has never been adequately recognized or protected by the U.S. Supreme Court under the (apparently) ambiguous terms "liberty," "property," "privileges," and "immunities," we look to other sources, where we find overwhelming evidence to support a conclusion that freedom of autonomy is a "natural right" entitled to full constitutional protec-

unconstitutional any government action that works an uncompensated physical or regulatory taking of the individual's property. See, e.g., Lucas v. South Carolina Coastal Commission, 505 U.S. 1003 (1992) (holding that a government action depriving an owner of virtually all of the property's value is a taking)); the Fourth Amendment Search and Seizure Clause; the Article I, section 10 Contracts Clause; and the Fifth and Fourteenth Amendment Due Process clauses. The Fifth Amendment Takings Clause and the Fourth Amendment Search and Seizure Clause are incorporated to apply to the states through the Fourteenth Amendment Due Process Clause. Professor Amar notes, "There is a ... conspicuous connection between the Fourth Amendment's limitations on 'seizures' of 'houses' and 'effects' and the Fifth's restrictions on 'takings' of 'private property.' In both cases, state law typically defines the property rights given constitutional protection against federal officials." AMAR, supra note 7, at 80 .

55. LEVY, supra note 2 at 252.

56. $I d$.

57. Id.

58. See supra note 39. 
tion..$^{59}$

On the second question of when, if ever, government can abridge a fundamental or natural right, we have at least a couple choices: (a) government is absolutely prohibited from infringing the right, under any circumstances, along the lines of Justice Black's position on government abridgments of speech; ${ }^{60}$ or (b) government is prohibited from infringing the right unless it demonstrates a compelling interest for doing so, and its infringement is narrowly-tailored. ${ }^{6}$

The balance in determining the appropriate involvement of government is delicate-reasonable minds may, and do, differ on this point. It would be easy to say that government should be absolutely prohibited from ever infringing the right, but this essay suggests that the latter strict-scrutiny approach would provide adequate protection for a newly-revived individual right of freedom of autonomy, while at the same time recognizing and accommodating the practical complexities of governing in a pluralistic nation of 300 million people. ${ }^{62}$

The First Amendment protection of freedom of speech $^{63}$ provides a useful analogue. The Court has made it clear through its First Amendment doctrine that absolute abridgements of speech will be upheld only in the very most extreme of circumstances, and partial deprivations only if in line with rigid guidelines. ${ }^{64}$ Generally speaking, strict scrutiny review is applied if the abridgement is contentbased, and intermediate scrutiny is applied if it is content-neutral, in which case reasonable content-neutral "time, place and manner re-

59. See supra notes 47-53; infra Section II.A. Amar describes a hierarchy of protection where the most fundamental "natural" rights are fully protected; and where "positive" rights (privileges granted by government) require equal treatment. "Equality" is itself a natural right of freedom of autonomy entitled to full protection.

60. Smith v. California, 361 U.S. 147, 157 (1959) (Black, J., concurring).

61. This is the Court's current strict-scrutiny approach to government intrusions on fundamental rights.

62. Ideally, and better yet, the Court would recognize and give effect to the Constitution's original "presumption of liberty" and limited conception of government authority, whereupon any government action infringing upon individual liberty is presumed unconstitutional until government meets its burden of demonstrating the action is "necessary" and "proper." See, e.g., BARNETT, supra note 42, at 253-69.

63. The First Amendment states that "Congress shall make no law . . . abridging the freedom of speech. ..." U.S. Const. amend. I.

64. The judiciary's First Amendment speech doctrine holds that any governmental abridgment of speech is presumed to be unconstitutional and will be upheld only if the government meets the burden of demonstrating that it meets the appropriate heightened standard of review. See, e.g., ERWIN CHEMERINSKY, CONSTITUTIONAL LAW 1045 (2005). A similar sort of framework could be applied to the freedom of autonomy. 
strictions"-i.e., those that provide reasonable alternatives for the speech - may be upheld. ${ }^{65}$ Federal and state policymakers have come to understand these guidelines and are careful in trying to write laws and regulations that will comply -thus providing a self-regulating mechanism for protecting speech.

A newly-revived and respected freedom of autonomy-most ideally, if not practically, stated in a constitutional amendment ${ }^{66}$ would have a similar effect on policymakers as they come to understand the following judicial doctrine: absolute deprivations of freedom of autonomy will be upheld in only the very most extreme of circumstances, and partial deprivations only if in line with rigid guidelines. Again, as with the First Amendment approach, strict scrutiny would be applied if the abridgement of the freedom of autonomy is content-based, and intermediate scrutiny if content-neutral, under which reasonable time, place and manner restrictions may be upheld. ${ }^{67}$

\section{A. The Nature of the Right}

A natural place to start any discussion of individual liberty (and, for purposes of this essay, freedom of autonomy) is with John Stuart Mill's famous "harm principle":

[There is but] one very simple principle, as entitled to govern absolutely the dealings of society with the individual in the way of compulsion and control ... that the sole end for which mankind are warranted, individually or collectively, in interfering with the liberty of action of any of their number, is self-protection. That the only purpose for which power can be rightfully exercised over any member of a civilized community, against his will, is to prevent harm to others.... The only part of the conduct of any one, for which he is amenable to society, is that which concerns others. In the part which merely concerns himself, his independence is, of right, absolute. Over himself, over his own body and mind, the individual is sovereign. ${ }^{68}$

65. See, e.g., Hill v. Colorado, 530 U.S. 703 (2000).

66. Citations we'd like to see: "Neither Congress nor any State shall make or enforce any law abridging any person's individual freedom of autonomy on matters of natural private concern." U.S. Const. amend. XXVIII.

67. See infra notes 124-30 and accompanying text.

68. J.S. MILL, ON LIBERTY 13 (1859, reprinted in Cambridge 2000). Shapiro writes, think of the harm principle as operating in two steps. When evaluating a particular action or policy, the first step involves deciding whether the action causes, or has the potential to cause, harm to others. If the answer is no, then the action is in the 
The harm principle captures the essence of the freedom of autonomy the framers "conferred, as against the government the right to be let alone - the most comprehensive of rights and the right most valued by civilized men." 69 Stated several other ways (it cannot be stated too frequently): government may not prohibit private individual behavior or action causing no harm to another; or on matters of natural private concern, an individual has the full right to behave or act in the manner of his or her choosing free of government interference; or government acts legitimately only insofar as it protects the individual's right to be left alone on matters of natural private concern.

Freedom of autonomy as conceptualized in this essay might be described as a sharpened version of the Millian harm principlesharpened, that is, to eliminate "social coercion" from its list of "harms" that must be prohibited. ${ }^{70}$ When it comes to social coer-

self-regarding realm and the government would be unjustified in interfering. Indeed, in that case the government has a duty to protect the individual's freedom of action against interference from others as well. If, however, the answer to the initial query is yes, then different considerations arise. We are then in a world in which harm is being committed willy-nilly, and the question is: What, if anything, should the government do about it? In this regard, a more accurate summation of the harm principle than the more famous formulation already quoted can be found at the start of chapter four: "As soon as any part of a person's conduct affects prejudicially the interests of others, society has jurisdiction over it, and the question whether the general welfare will or will not be promoted by interfering with it becomes open to discussion. But there is no room for entertaining any such discussion when a person's conduct affects the interests of no persons besides himself."

SHAPIRO, supra note 18, at 60-61 (quoting JOHN STUART MILL, ON LIBERTY (Indianapolis: Hackett, 1978 [1859], p. 73).

69. Olmstead v. United States, 277 U.S. 438, 478 (1928) (Brandeis, J. dissenting); see supra note 17 and accompanying text.

70. Jed Rubenfeld argues effectively in FREEDOM AND TIME (Yale 2001) that Mill goes too far in adding freedom from social coercion to freedom from legal coercion to the formula for determining "the limit to the legitimate interference of collective opinion with individual independence." JED RUBENFELD, FREEDOM AND TIME 230 (Yale Univ. 2001). Mill states,

As soon as any part of a person's conduct affects prejudicially the interests of others, society has jurisdiction over it. ... But ... when a person's conduct affects the interests of no person besides himself, or needs not affect them unless they like... there should be a perfect freedom, legal and social, to do the action and stand the consequences.

Id. (quoting John Stuart Mill, On Liberty [1859], in ON LIBERTY AND CONSIDERATIONS ON REPRESENTATIVE GOVERNMENT LVIII (R.B. McCallum ed., Oxford 1946) (emphasis added). Rubenfeld points out that by so asserting, Mill open[s] himself up a: startling internal paradox[] that the old arguments have overlooked." Id. at 231. Specifically, on one hand Mill asserts that in determining what sort of "harm" is sufficient, there must be "direct harm to others ... [and] definite damage[s], or a definite risk of damage.... [M]inor ... inconvenien[ces that do not] ... prejudicially affect 
cion, people simply need to develop means other than legal recourse to deal with the problem. ${ }^{71}$ It is only when social coercion gives way to official legal coercion, ${ }^{72}$ or perhaps when it becomes so oppressive and systematic as to amount to virtual official coercion, ${ }^{73}$ that this essay's freedom of autonomy definition of "harm" is implicated.

This narrower sharpened version of the harm principle does not fear standardization per se but rather accepts it as a fact of life, as long as those who would be "standardized" do so of their own will, free of legal coercion. Some degree of standardization is to be expected and, indeed, desired-it's called community. And as much as Burkean or communitarian critics would have us believe it to be so, ${ }^{74}$ individualist liberalism and community are not mutually exclusive concepts. ${ }^{75}$ Community provides positive, nurturing

others are not enough to justify society's legitimate interference with individual independence. Id. at 230 (quoting and citing Mill, supra at 67-73). On the other hand, though, in criticizing and seeking to forbid the "social tyranny" and "despotism of custom" that would stunt individual freedom, Mill is himself "engaged in the putatively non-regulable conduct that liberalism is supposed to protect. What is floridly called 'social tyranny,' what is most threatening to individual autonomy, in fact turns out to be itself an exercise of individual autonomy-by the intolerant." Id. at 232. According to Rubenfeld, then, "the individualist, Millian liberalism that we admire so much ... is itself the source of standardization that liberalism fears." Id. at 232.

71. Unfortunately people can be mean - that much is evident from a very early age on the playground. Difficult though it is, a person behaving in a way that is in variance with that of the "crowd" on the playground of life needs to develop a thick skin and/or be willing to push back from time to time.

72. When the school principal exercises the authority of the office to give the outlier person detention, as it were...

73. Extending the analogy once more-when the principal stands by the side of the playground and observes with arms folded while the crowd torments and ridicules the outlier person day in and day out, for example.

74. Michale Walzer writes,

What is often taken to be the central issue between liberals and their communitarian critics - the constitution of the self. Liberalism, it is commonly said, is founded on the idea of a presocial self, a solitary and sometimes heroic individual confronting society, who is fully formed before the confrontation begins.... The [communitarian] critics are commonly said in turn to believe in a radically socialized self that can never "confront" society because it is, from the beginning, entangled in society, itself the embodiment of social values... . Neither of these views can be sustained for long by anyone who goes beyond staking out a position and tries to elaborate an argument.

Michael Walzer, Politics AND PASSiOn 161-63 (Yale 2004).

75. Michael Walzer points out that,

[1]iberalism is distinguished less by the freedom to form groups on the basis of these identities than by the freedom to leave the groups and sometimes even the identities behind. Association is always at risk in a liberal society. The boundaries of the group are not policed; people come and go, or they just fade into the distance without ever quite acknowledging that they have left. ... At its best, the liberal society 
social arrangements for human beings, who are, after all, social beings. ${ }^{76}$ The value of community diminishes greatly, though, if it loses its elective character. ${ }^{77}$

It is difficult at first to grasp the full magnitude of the freedom of autonomy concept - that individuals have total freedom on matters of natural private concern. ${ }^{78}$ "No, it can't be," we say, "there must be a catch." But the only "catch" is that we have become so conditioned to being told by government-mere people, after all, but acting under the guise and false authority of "government"-how we may behave, that it seems impossible to believe we may really be so free. ${ }^{79}$

is the "social union of social unions" that John Rawls described: a pluralism of groups bonded by shared ideas of toleration and democracy.

WALZER, supra note 74, at 155.

76. Some "[i]nvoluntary association is a permanent feature of social existence, and the people who fight for equality, like those who struggle to be free, are inevitably its creatures," and to be sure, "[d]enial is foolish, and abolition is impossible." Id. at 1,2 . Walzer identifies four kinds of involuntary associations faced by all persons from very early in life: (1) familial and social ("We are born members of a kin group, of a nation or country, and of a social class; and we are born male or female. These ... attributes go a long way toward determining the people with whom we associate for the rest of our lives."). Id. at 4; (2) cultural dictates ("Associates may choose one another, but they rarely have much to say about the structure and style of their association. Marriage is the obvious example.... Even radically new associational practices are likely to mimic old forms-the way gay unions mimic the modern nuclear family and aim at the same legal recognition.") $I d$. at 6 ; (3) political ("[W]e are born citizens ... and are rarely invited to agree to our citizenship.... [Citizens] can choose to vote or not, to join this or that party or movement, to form a caucus or oppositional faction, or to avoid political activity entirely.... [But] there is one thing they can't do: they can't work or live someplace and refuse the rights of citizenship - and the burdens, too, such as taxes and union dues."); $I d$ at 7; and (4) moral--people "hear an internal voice of constraint, telling them that they should do this or that... In time of trouble [one's nation, race or religion, for example, people may feel themselves to be morally] bound to stay and help their fellow citizens. . . Indeed, I am likely to acknowledge the constraint even if I refuse to respect it-by the excuses I offer, the urgent reasons I invent, as I pack my bags." Id. at 9-10.

77. "What makes any identity or affiliation voluntary is the easy availability of alternative identities and affiliations. What makes a marriage voluntary, [for example,] is the permanent possibility of divorce." Id. at 161-63. In this sense the idea of separation/secession, supra note 36 , is itself a liberal idea-the national association is voluntary.

78. See infra note 84 and accompanying text (discussing two-tier analysis). On matters of positive (i.e., having been granted by government), as opposed to natural, private concern, the freedom is not "total," but rather "relative" in the sense that irrational discrimination is prohibited. Rawlsian concepts are helpful in describing the sort of equality that exists within freedom of autonomy: "Ignorant of their religion, race, ethnicity, gender, or social status behind the veil of ignorance... [a]ssuming that they would always be in the group disadvantaged by the denial of equality of access to advancement, [people] would instead embrace a principle of equality of opportunity." SHAPIRO, supra note 18, at 132-33.

79. Randy Barnett puts it thus:

The Constitution that was actually enacted and formally amended creates islands of government powers in a sea of liberty. The judicially redacted constitution creates 
We must constantly remind ourselves, and continue to insist in the face of an overbearing government, that this freedom is rightfully ours in the first instance-freedom of autonomy is the rule in nature, not the exception-and it is accordingly the government ${ }^{80}$ that has been acting inappropriately all along in "creat[ing] a society with a network of small complicated rules, minute and uniform, that none can escape ... [leading then to a citizenry] reduced to nothing better than a flock of timid and industrious animals, of which the government is the shepherd." ${ }^{\prime 1}$ It is OUR individual freedom-and we must reclaim it from government. ${ }^{82}$ If we continue to accept this status quo, we really are just timid sheep, as Tocqueville predicted.

The founding and framing generations had a deep aversion to the unjust exercise of political "power," aware as they were of its rapa-

islands of liberty rights in a sea of governmental power. Judicial redaction has created a substantially different constitution from the one written on parchment that resides under glass in Washington. Thought that Constitution is now lost, it has not been repealed, so it could be found again.

BARNETT, supra note 42, at 1.

80. Friedrich Nietzsche wrote about the dangers of government in his own inimitable fashion:

State is the name of the coldest of all cold monsters.... And this lie crawls out of its mouth: "I, the state, am the people." That is a lie! It was creators who created peoples. ... It is annihilators who set traps for the many and call them "state": they hang a sword and a hundred appetites over them. ... It has invented its own language of customs and rights. ... Behold, how it lures them, the all-too-many-and how it devours them, chews them, and ruminates! "On earth there is nothing greater than I: the ordering finger of God am I"- thus roars the monster.... Alas, to you too, you great souls, it whispers its dark lies.... It will give you everything if you will adore it, this new idol: thus it buys the splendor of your virtues and the look of your proud eyes. ... My brothers, do you want to suffocate. ..? Rather break the windows and leap to freedom.... Only where the state ends, there begins the human being who is not superfluous: there begins ... the unique and inimitable tune. Where the state ends-look there, my brothers!

Friedrich Nietzsche, Thus Spoke Zarathustra: A Book For One and All 48-51, 188 (Penguin ed. 1978 Walter Kauffman trans.). Granted, Nietzsche is over the top, but the point is valid that government will, if allowed to do so, insidiously inject its own "customs and rights" in place of those of the individual. That is precisely the point of this article-that government has stolen individual freedom of autonomy in America.

81. DAHL, supra note 6, at 233 (quoting de Tocqueville, supra note 19).

82. This view of the nature of rights is reflected in Ohioan Salmon P. Chase's famous oral argument in the 1847 fugitive slave case of Jones $v$. Van Zandt:

The provisions of the constitution, contained in the amendments... rather announce restrictions upon legislative power, imposed by the very nature of society and of government, than create restrictions, which, were they erased from the constitution, the Legislature would be at liberty to disregard. No Legislature is . . at liberty to disregard the fundamental principles of rectitude and justice.

AMAR, supra note 7 , at 162 and accompanying text. 
cious nature, ${ }^{83}$ knowing that the governed must be ever vigilant to keep it at bay within its assigned confines. ${ }^{84}$ "'Power' to them meant the dominion of some men over others, the human control of human life: ultimately, force, compulsion.... Most commonly the discussion of power centered on its essential characteristic of aggressiveness: its endlessly propulsive tendency to expand itself beyond legitimate boundaries. ...,

83. Bailyn Writes,

Not that power was in itself-in some metaphysical sense--evil. It had legitimate foundations "in compact and mutual consent"-in those covenants among men by which, as a result of restrictions voluntarily accepted by all for the good of all, society emerges from a state of nature and creates government to serve as trustee and custodian of the mass of surrendered individual powers.

BAILYN, supra note 5, at 58-59.

[T] he point they hammered home time and again, and agreed on-freethinking Anglican literati no less than neo-Calvinist theologians-was the incapacity of the species, of mankind in general, to withstand the temptations of power. Such is "the depravity of mankind," Samuel Adams, speaking for the Boston Town Meeting, declared, "that ambition and lust of power above the law are ... predominant passions in the breasts of most men." Power "converts a good man in private life to a tyrant in office." It acts upon men like drink: it "is known to be intoxicating in its nature"-.." too intoxicating and liable to abuse." And nothing within man is sufficiently strong to guard against these effects of power - certainly not "the united considerations of reason and religion," for they have never "been sufficiently powerful to restrain these lusts of men."

Id. at 60 (citing Eliot, sermon (JHL 15), pp. 10-11, etc.)

84. An influential writing of the day, "Molesworth's An Account of Denmark (1694)[,] established the general point ... that the preservation of liberty rested on the ability of the people to maintain effective checks on the wielders of power, and hence in the last analysis rested on the vigilance and moral stamina of the people." BAILYN, supra note 5, at 65 . Bailyn writes, "The acuteness of the colonists' sense of this problem is, for the twentieth-century reader, one of the most striking things to be found in this eighteenth-century literature: it serves to link the Revolutionary generation to our own in the most intimate way." Id. at $57,58$.

85. Bailyn writes,

The essence of what the colonists meant by power was perhaps best revealed by John Adams as he groped for words in drafting his Dissertation on the Canon and Feudal Law. Twice choosing and then rejecting the word "power," he finally selected as the specification of the thought he had in mind "dominion," and in this association of words the whole generation concurred.... It is everywhere in public life, and everywhere it is threatening, pushing and grasping; and too often in the end it destroys its benign-necessarily benign-victim.... What gave transcendent importance to the aggressiveness of power was the act that its natural prey, its necessary victim, was liberty, or law, or right. The public world these writers saw was divided into distinct, contrasting, and innately antagonistic spheres: the sphere of [government] power and the sphere of liberty or right. The one was brutal, ceaselessly active, and heedless; the other was delicate, passive, and sensitive. The one must be resisted, the other defended, and the two must never be confused.

BAILYN, supra note 5, at 57-58 (citations omitted). 
Of course "We the People" understand that we cannot have absolute free reign-we do, after all, live in a nation with three hundred million other souls, and to the extent our behavior harms or concerns others, we accept that we must yield, and we entrust to government the authority to manage those things that government necessarily and properly manages. ${ }^{86}$ Moreover, we understand that even if our behavior does not harm or concern others, government may in the proper circumscribed exercise of its responsibilities sometimes find it necessary and proper to impose, within strict guidelines, "reasonable content-neutral time, place and manner restrictions" that may affect our activity. ${ }^{87}$

We also understand we may expect a different level of constitutional protection depending on whether our activity involves a natural right or a positive right. Classic "freedom of autonomy" rights are natural rights, those pre-political liberties existing as a part of the greater order possessed by every individual from birth that cannot be extinguished by any mere human government, and are entitled to full protection whereas positive rights, those granted through the political process (common-law, state law, federal law, or otherwise) are entitled to relative equality of protection (i.e. the government may not arbitrarily discriminate in granting and enforcing those rights. $)^{88}$ So, for

86. The devil is in the details of course-in this case, what does it mean to "harm" or "concern" others? To be sure, in a butterfly-effect sense, one's activity always affects others in some way, however infinitesimally, but for our purposes the terms are strictly defined-to use a tort or criminal law analogue, there must be some cognizable "injury." One's actions emphatically do NOT "harm" or "concern" if they "disgust," "repulse," "anger," "upset," "disappoint," or otherwise "offend" others. Others' own opinions on moral and social issues are just that-opinions, and their opinions do not rule us. We don't presume to tell others how to live their lives - and we especially don't attempt to add the coercive powers of government to impose our opinions on them-and we expect and demand the same treatment in return.

87. As with the Court's analogous First Amendment doctrine, the key is that the regulation does not work an outright ban on the activity - the activity may still occur at a alternative reasonable time or place, or in an alternative reasonable manner. See supra notes 59-64 and accompanying text.

88. Professor Amar proposes this sort of two-tier system as a tool for assigning the proper level of protection originally contemplated for various "privileges-or-immunities" of Section I of the Fourteenth Amendment: "Section I is not limited to privileges and immunities specified in the pre-1866 Constitution. Other, common-law rights were also included. ... For those nonconstitutional rights, perhaps only antidiscrimination ("equal") protection should be accorded, rather than fundamental rights ("full") protection." AMAR, supra note 7, at 178 (citing John Harrison, Reconstructing the Privileges or Immunities Clause, 101 Yale L.J. 1385 (1992); Earl M. Maltz, Fourteenth Amendment concepts in the Antebellum Era, 32 AM.J. LEGAL HIST. 305, 323 (1988). For similar views, see 1 D. CURRIE, THE CONSTITUTION IN THE SUPREME COURT 347-50 (1985); WILLIAM E. NELSON, THE FOURTEENTH AMENDMENT 115-24 (1988)." AMAR, supra note 7, at 367. Amar doesn't use the terms "natural law" and 
example, whereas sexual freedom and freedom of association are natural rights and thus entitled to full protection, marriage of any description (same-sex, different-sex) is entitled to equal protection as a positive right. ${ }^{89}$ Under similar reasoning, freedom of association (in all circumstances, economic included) is a natural right and thus entitled to full protection whereas, economically-based associations created by state law or by common-law (e.g., contracts), are positive rights entitled to equal protection. ${ }^{90}$

\section{B. Freedom of Autonomy Applied}

Consider five activities: three currently prohibited by government-same-sex marriage (sexual freedom), right to die; and possession/use of soft drugs (marijuana) $;{ }^{91}$ one formerly prohibited and currently under heavy attack-abortion; and one protected from the beginning, but becoming less well-protected in the modern erareligion. We could go on, but for our purposes, the point is illustrated by these several examples. ${ }^{92}$

"positive law" in this passage (perhaps they are implicit), but the same two-tier system is useful in determining the proper level of protection for those freedom of autonomy rights, not otherwise explicitly "specified and 'declared' by We the People [in the Constitution and hence] were easy cases for full protection," that exist as a matter of natural law (deserving of "full" protection) as opposed to positive law (deserving of "equal" protection). AMAR, supra note 7, at 179 . It also bears repeating that the right of equality generally, free of context, is itself a natural right entitled to full protection. See supra note 53 and accompanying text.

89. See infra notes $93-100$ and accompanying text.

90. Amar offers the two-tier approach as a possible solution to the troubling "specter of judges invalidating statutes by invoking nontextually specified fundamental rights and by giving constitutional status to common-law rights like freedom of contract... [ala Lochner. ..." AMAR, supra note 7, at 178 (citing Lochner v. New York, 198 U.S. 45 (1905)). For another intriguing, un-p.c. perspective on Lochner, see BARNETT, supra note 42, at 21118.

91. Many-perhaps even most-Americans will respond, "Of course these activities are prohibited - what sort of decent society would not do the same?" A literal answer would be, "Decent countries not doing the same include, to varying degrees, The Netherlands, Belgium, and more recently, Canada." This is where Americans must be reconditioned to reframe the question to one that more accurately reflects the spirit of the modern Enlightenment and of America's own founding generation, "I may personally disagree with the activities, but what sort of decent government would [deign to] presume to tell individuals how they should and should not behave?" The point is, we start, and operate, with a presumption of liberty.

92. "Life" itself might be said to be the ultimate autonomy freedom, in which event the U.S. Supreme Court's allowance under the Fifth and Fourteenth Amendments due process clauses of federal and state governments' use of the death sentence would violate this freedom. The death sentence is an entirely separate discussion-those convicted of capital crimes in those states allowing the death penalty have caused grievous harm to another. Because this essay's "freedom of autonomy" is premised on liberty to act in any way that does not harm another (or, at most, only nominally harms another), this essay does not include "life" in its 


\section{Same-sex Marriage (Sexual Freedom)}

The institution of marriage, created as it is by common-law and state law, is a positive right entitled to equal constitutional protection $;{ }^{93}$ whereas sexual freedom, the individual liberty one would exercise within any marriage, ${ }^{94}$ is a natural right entitled to full constitutional protection. This much has been essentially recognized by the Supreme Court in the 2003 case Lawrence v. Texas, ${ }^{95}$ which held that private sexual activity is protected as right of privacy under the Fourteenth Amendment due process clause. ${ }^{96}$ While Lawrence was an important victory for freedom of autonomy, the very narrowness of the margin (6-3 and 5-4) is telling on the point that freedom of autonomy protection, even where it exists, is tenuous at best-demonstrating yet again the ideal solution of constitutional amendment to provide more lasting protection.

As noted, marriage is a positive right entitled to equal constitutional protection. This much most assuredly has not been recognized by the Supreme Court, by the thirteen states passing constitutional amendments in 2004 banning same-sex marriage, ${ }^{97}$ or by numerous other governmental bodies that discriminate against same-sex cou-

definition of freedom of autonomy.

93. See supra note 90 and accompanying text describing of two-tier framework designating "full" protection for natural rights and "equal" protection for positive rights. To the extent one might suggest that polygamy should likewise be treated equally under the two-tier framework, arguably freedom of autonomy does not extend to associations where the terms are extremely unfavorable toward one class of people (in this case women) who possess a severe deficit of bargaining power. See generally JON KRAKAUER, UNDER THE BANNER OF HEAVEN: A STORY OF VIOLENT FAITH (2003) explainingthe realities of the institution of polygamy).

94. Freedom of association is another natural right one exercises in making a decision to marry-a right that is on firm footing in the Court's First Amendment speech doctrine.

95. 539 U.S. 558 (2003). See supra note 4.

96. Lawrence, 539 U.S. at 578 . The Court struck down a state law prohibiting certain specified sexual behavior (sodomy) on two separate grounds: (a) substantive due process (privacy); and (b) equal protection, reversing its earlier decision in Bowers v. Hardwick, 478 U.S. 186 (1986), which had held that government infringements on private sexual activity were entitled to deferential rational-basis review. See, e.g., RANDY BARNETT, JUSTICE KENNEDY'S LIBERTARIAN REVOLUTION: LAWRENCE V. TEXAS, 2003 Cato Sup. Ct. Rev. 21, 21 (2003) (writing that "what was most striking about Lawrence was the way the Court justified its ruling. If the approach the Court took in the case is followed in other cases in the future, we have in Lawrence nothing short of a constitutional revolution, with implications reaching far beyond the "personal liberty" at issue here... [T] [Te Lawrence majority did not protect a "right of privacy.' Instead, quite simply, they protected 'liberty."').

97. See supra note 8 (commenting that the amendments were ostensibly to ban same-sex marriage, but in fact their intent and scope are far broader than that in curbing the rights of gay Americans.) 
ples. Government offers legal recognition to married couples. With legal recognition comes certain benefits; for example, spouses are entitled by law to social security benefits, consideration under intestacy statutes, and medical insurance. By electing to extend these benefits to one group of people (heterosexual couples), but not to another (same-sex couples), based on the manner that the two groups exercise an underlying natural right entitled to full constitutional protection, government engages in irrational discrimination and deprives the individuals in the same-sex couples of their freedom of autonomy.

If I decide I want to marry another man, my action does not harm or injure another. Does it disgust some and repulse others? Yes. But the fact that majorities may find the private activities of a disfavored minority distasteful or even repulsive does not give the majority a right, through abusive and illegitimate use of government mechanisms, to impose their own values on the minority. If the majority decides instead to remove legal recognition of marriage for all, it may legitimately do so, ${ }^{98}$ but it may not disfavor one group by failing to extend the same positive rights to that group as it does to the favored group.

Even if one's sexual orientation were a matter of choice, ${ }^{99}$ arguments suggesting that same-sex marriage threatens the institution of traditional heterosexual marriage ignorantly fail to account for the innate biological drive to perpetuate the species. There are few instincts more powerful-as long as humans continue to walk the face of the earth, a critical mass will enter into associations, such as heterosexual marriage, that lend themselves to the perpetuation of the species. $\mathrm{Bi}$ ology does not need the help of moralistic conservative Christians. Moreover, and perhaps more basically still, how can long-term committed loving relationships be wrong, to the point where government

98. The Supreme Court has held that the right to marry, as part of the larger right of family autonomy, is fundamental. See Loving v. Virginia, 388 U.S. 1, 12 (1967). In this context, "fundamental" is not analogous to "natural." Marriage, though described as "fundamental" by the Court for purposes of its substantive due process privacy doctrine, simply is not a natural right. To the extent the Court would suggest otherwise, it misconceives the right. The fact that the state does not endorse a particular institution does not mean that people may not continue to exercise the natural right of association to cohabitate and spend their lives together and consider themselves as "married" for their own purposes, but the state is not required to recognize the institution in the first instance.

99. There are many arguments for and against on this point-with the more persuasive that one's sexual orientation is not a matter of choice; rather, it is innate. Whether sexual orientation is or is not a matter of choice matters not one whit one way or another to the freedom of autonomy principle. 
will not support them?

In sum, the fact that the judiciary does not consistently ${ }^{100}$ recognize the obvious equal protection problems ${ }^{101}$ in such discrimination is ample evidence that judicial review, important as it is, ultimately is inadequate to protect the freedom of autonomy rights of an oppressed minority from majority tyranny.

\section{Right to Die}

I may have a terminal physical condition that irreparably impairs my quality of life and elect, after much thought, that I wish to end my suffering by hastening my own death. Does my action harm or injure others? No. Does it upset and offend some others? Yes. But as Bishop John Shelby Spong, ${ }^{102}$ an articulate Christian spokesperson favoring choice in end-of-life decisions, puts it, "I believe that if and when a person arrives at that point in human existence when death has become a kinder alternative than hopeless pain ... then the basic human right to choose how and when to die should be guaranteed by law and respected by our communities of faith. ... My deepest desire is always to choose death with dignity over a life that has become either hopelessly painful and dysfunctional or empty and devoid of all meaning. ... That does not seem to me to be too much to ask my faith to give me or my government to guarantee for me."103

100. Courts are all over the board on this. See infra note 196.

101. Put it this way: If a recount of votes in Florida in the 2000 presidential election, as had been ordered (as required under state law) by the highest court in the sovereign state of Florida, violates the equal protection of voters, see Bush v. Gore, 531 U.S. 98, 110-11 (2000), certainly failing to extend the same marriage benefits to a person based on the fact he or she wishes to marry someone of the same gender is also an equal protection violation.

102. Mr. Spong is Eighth Bishop of Newark of the Episcopal Church. At the time of his retirement in 2000 Bishop Spong was the senior active bishop in the Episcopal Church in the United States.

103. John Shelby Spong, Death: A Friend to be Welcomed Not an Enemy to be Defeated, Address to the Nat'l Convention of the Hemlock Society (January 10, 2003) (transcript available at http://www.endoflifechoices.org/files/resource/spong\%20address\%202003.pdf). Bishop Spong, on the credibility of Christian moralizing about the sanctity of life:

If human beings who call themselves Christians have no scruples about endorsing war, killing religious enemies or imposing the sentence of death upon those who violate either the norms of faith, or the boundaries of prejudice under a particular set of circumstances in the past, is it still appropriate for Christians to suggest that one cannot elect death for himself or herself under a different set of circumstances in the present? It seems to me that a certain irrational inconsistency is operating here, which needs to be pointed out to any faith community that espouses such claims.

Id. at 4.

And on the Christian view of death: 
And there are government voices of reason on this issue as well, such as California Assembly member Lloyd Levine commenting in support of the Compassionate Choice Act of 2005, an aid-in-dying bill introduced this year in the California Assembly: "This is a very personal issue.... It is not up to me to substitute my moral views on you, and it's not up to anyone else to substitute their moral views on anyone else"; ${ }^{104}$ and former Vermont governor Phil Hoff, speaking in support of the Vermont Death with Dignity Act of 2005 currently under consideration by the Vermont legislature: "While I respect people making different choices for themselves, a small minority of Vermonters should not be able to impose their views on the vast majority of Vermonters that want more choice and control at the end of our lives." $" 105$

Oregon is the only state to date that has enacted legislation (the 1998 Oregon Death with Dignity law) protecting this natural individual right of freedom of choice in end-of-life decisions. All of the current legislative efforts - the Oregon law as well as the proposed legislation in Vermont and California-share several elements that must be met if a person is to self-hasten death in accordance with law: "[(i)] a person must be a terminally ill adult, [(ii)] two doctors must agree that the person is competent (either doctor may require psychological testing), [(iii)] the request must be made three separate times and may be withdrawn at any time, and [(iv)] the person must acquire the medication and the medication must be self-administered."106

But let there be no mistake about what is happening. These stirring [technological] achievements [expanding life expectancy] represent human beings taking on the power we once ascribed only to God. We have by our own knowledge and expertise put our hands on the decisions about life and death. We cannot now refuse to engage these decisions at the end of our own lives.... We have watched human life actually evolve to where it must accept God-like responsibilities. The time has come to celebrate that, not to hide from it in the language of piety.... It is one thing, however, to expand life and it is quite another to postpone death. When medical science shifts from expanding the length and quality of life and begins simply to postpone the reality of death, why are we not capable of saying that the sacredness of life is no longer being served, and therefore Christians must learn to act responsibly in the final moments of life. Id. at 9.

104. COMPASSION \& Choices, AdVocaCy Bulletin (Vol. II, Issue II March 14, 2005), at http://www.endoflifechoices.org/files/article/bulletin 03.05.pdf (last visited Nov. 8, 2005).

105. Id.

106. End-Of-Life Choices, Frequently-Asked-Questions, at http://www.endoflifechoices. org/learn/index.jsp (last visited Nov. 8, 2005). The Oregon Department of Human Services' recent report on the seventh year statistics on the law "show that 37 people ended their lives 
As reflected by these state efforts, end-of-life choice is one individual freedom of autonomy interest a solid majority of the People apparently do support ${ }^{107}$ - perhaps because they recognize that they themselves, rather than some nameless others, may desire to exercise the right at some future date. Thus it is disappointing, though of course unsurprising and entirely consistent, that Congress and the Bush administration would seek to remove this freedom and impose their own set of moral views on others - and so have sued to have the Oregon law declared unconstitutional. ${ }^{108}$ The government's lawsuit seeking to remove an individual liberty previously protected by state law is grossly inappropriate on two levels: one, for our immediate purposes, it fails to protect individual freedom of autonomy on a matter of natural private concern; two, it violates principles of comity in federal-state relations by interfering with the policy determination of a sovereign state engaged in regulating, under its Tenth Amendment reservation of authority, a matter reserved to state governments. This is another instance of overbearing federal interference with individual autonomy and with state prerogative ...this is why We the People need a constitutional amendment protecting freedom of autonomy.

\section{Soft Drugs}

For close to 400 years-from the time of the first American hemp crop in 1611 near Jamestown, Virginia through the turn of the twentieth-century-marijuana (then known as hemp) was grown in America for its fiber content. Indeed, "King James I of Britain or-

under the law in 2004 , slightly fewer than in 2003 . As required by law, all were terminally ill and made repeated and voluntary requests for assistance." COMPASSION \& CHOICES, supra note 104.

107. Seventy percent of respondents to a 2005 Field Poll in California "agreed that a mentally competent, terminally ill adult should be able to receive aid from their doctor to die peacefully." COMPASSION \& CHOICES, supra note 104. (citing www.caforaidindying.org).

In a recent poll conducted by Zogby International in Vermont, "[n]early 80 percent of respondents said they would support a bill allowing terminally ill patients to receive medication from their doctors to hasten their deaths." Id. (citing www.choicesvermont.org). An Episcopalian convention of the Diocese of Newark, consisting of 450 elected lay people and 150 ordained Episcopalian clergy, after a year of open hearings "endorsed by a 2 to 1 majority ... physician assisted suicide as a moral option for Christians." Spong, supra note 98 at 1-2 (citing www.dioceseofnewark.org).

108. The Oregon law prevailed at the Ninth Circuit Court of Appeals, Oregon v. Ashcroft, 368 F.3d 1118 (9th Cir. 2004), and the Supreme Court has agreed to hear the government's appeal in Gonzales v. Oregon, with oral arguments scheduled for Fall 2005. The government argues that the federal Controlled Substances Act authorizes the government to preempt state regulations allowing the use of such substances in the end-of-life choice process. 
dered settlers to engage in wide scale farming of the plant. Most of the sails and ropes on colonial ships were made from hemp as were many of the colonists' bibles, clothing and maps. [And in the most delicious irony of all, according to some historians, George Washington and Thomas Jefferson cultivated marijuana and advocated a hemp-based economy." 109

Fast forward to the twenty-first century, when use or possession of marijuana is illegal and aggressively enforced (734,000 criminal arrests per year) and prosecuted by the federal and many state governments, at a cost of anywhere from $\$ 7.5-\$ 10$ billion per year. Aside from being crazy policy (crazy or not, policy is ordinarily within the proper realm of a democratically-elected legislature), ${ }^{110}$ the government's zeal in apprehending and punishing even minor offenders who would use marijuana occasionally is just plain bizarre. ${ }^{111}$ The odd-

109. THE NAT'L ORG. FOR THE REFORM OF MARIJUANA LAWS, NORML REPORT ON SIXTY YEARS OF MARIJUANA PROHIBITION IN THE U.S., 3 (2003), at http://www.norml.com/pdf_files/NORML_Report_Sixty_Years_US_Prohibition.pdf (last visited Nov. 8, 2005).

110. Objectively, there are numerous policy reasons to decriminalize marijuana: (1) cost of enforcement- - taxpayers annually spend between $\$ 7.5$ billion and $\$ 10$ billion arresting and prosecuting individuals for marijuana violations, [with approximately 734,000 or more annual arrests] than the total number of arrestees for all violent crime combined, including murder, rape, robbery and aggravated assault"; (2) harm caused by criminal prohibition of marijuana is much greater than harm caused by marijuana use itself-As former President Jimmy Carter said, "Penalties against drug use should not be more damaging to an individual than the use of the drug itself. Nowhere is this more clear than in the laws against the possession of marijuana in private for personal use"; (3) decriminalization does not lead to increased marijuana useMore than 30 percent of the U.S. population lives under some form of marijuana decriminalization (Alaska, California, Colorado, Maine, Minnesota, Mississippi, Nebraska, Nevada, New York, North Carolina, Ohio and Oregon), and according to government and academic studies, these laws have not contributed to an increase in marijuana consumption-moreover, decriminalization appears to reduce rates of hard drug use in states that have decriminalized; (4) medical benefits:

Written references to the use of marijuana as a medicine date back nearly 5,000 years. Western medicine embraced marijuana's medical properties in the mid$1800 \mathrm{~s}$, and by the beginning of the $20^{\text {th }}$ century, physicians had published more than 100 papers in the Western medical literature recommending its use for a variety of disorders.

Twelve states (Alaska, Arizona, California, Colorado, Hawaii, Maine, Maryland, Montana, Nevada, Oregon, Vermont and Washington) have legalized marijuana for medical use. The National Organization for the Reform of Marijuana Laws, at http://www.norml.com (citing numerous sources), (last visited April 20, 2005).

111. Marijuana is no different than other soft drugs like alcohol and tobacco. It may be similarly taxed and regulated. As with alcohol, for example, it becomes a matter of public concern if I operate a motor vehicle while under the influence of marijuana, since chances are increased that I may have an accident and cause physical harm or injury to another; accordingly, government is justified in preventing me from mixing the activities. Indeed, if legisla- 
ness started in the 1920s and in 1930 with the government's establishment of the Federal Bureau of Narcotics (FBN). In response to an FBN-sponsored campaign, reefer-madness hysteria took hold in the 1930s, prompting 27 states to pass laws prohibiting marijuana. "For example, a news bulletin issued by the FBN in the mid-1930s purported that a user of marijuana 'becomes a fiend with savage or 'caveman' tendencies. His sex desires are aroused and some of the most horrible crimes result. He hears light and sees sound. To get away from it, he suddenly becomes violent and may kill.""112

The "Marihuana Tax Act of 1937," criminalizing the possession or use of marijuana, was passed after two Congressional hearings (one House, one Senate) totaling just one hour, after debate in the House lasting 90 seconds, and with similar alacrity in the Senate. In the House Ways and Means Committee hearing, two witnesses, the head of the FBN and a Treasury Department Assistant General Counsel, testified in favor of the bill, and a physician representative from the American Medical Association (AMA) testified against. The committee took little interest in the AMA's views, however, telling the physician, "If you want to advise us on legislation, you ought to come here with some constructive proposals ... rather than trying to throw obstacles in the way of something that the federal government is trying to do." Adding insult to injury, during the 90 seconds of debate in the House, a member of the committee lied in response to a question ${ }^{113}$ of whether the AMA supported the bill, stating, "Their Doctor ... gave this measure his full support ... [as well as] the approval [of] the American Medical Association."114

And the federal government-sponsored hysteria, as regrettably enabled by the Supreme Court, ${ }^{115}$ continues to this day. The point for

tures stopped to think with some clarity on the issue, they would recognize that another weed, tobacco, has been a major contributor to state economies (as was hemp, see supra text accompanying note 109) from the earliest pre-Revolutionary days.

112. NORML Report, supra note 109, at 3 (citing Lester Grinspoon, M.D., Marihuana Reconsidered, at 11(2d ed.) (San Francisco: Quick American Archives, 1994)).

113. The only other question asked for a summary of the bill, to which Speaker Sam Rayburn replied, "I don't know. It has something to do with a thing called marijuana. I think it's a narcotic of some kind." NORML Report, supra note 109, at 4.

114. NORML Report on Sixty Years of Marijuana Prohibition in the U.S., at http://www.norml.com/index.cfm?Group_ID=4428. (last visited Sep. 17, 2005).

115. See Gonzales v. Raich, 125 S.Ct. 2195, 2219 (2005) where the Court agreed with the Bush administration's broad commerce clause arguments to strictly interpret and enforce the federal Controlled Substances Act against the State of California's law allowing the prescribed medical use of marijuana. 
our purposes is that the government's prohibition of marijuana by any means (including its current over-the-top approach) violates the individual right of freedom of autonomy on matters of natural private concern. ${ }^{116}$ As James Madison wrote, speaking on behalf of a founding generation overwhelmingly "focused on the effort to free the individual from the oppressive misuse of power, from the tyranny of the state," 117 every person has a "[right] in the free use of his faculties and free choice of the objects on which to employ them."

\section{Abortion}

If we accept for a moment (for purpose of argument only) that life-with its full set of intact constitutional protections-begins at conception, ${ }^{119}$ abortion presents the especially hard case where one person's exercise of individual freedom of autonomy not only interferes with the autonomy rights of another, but actually causes an absolute deprivation of the other's rights-the classic zero-sum game.

116. Any harm or injury caused by a person using marijuana is to that individual alone, no one else. As with tobacco and alcohol there is an expense to society in the form of healthcare cost and loss of productivity, but these are costs of freedom-much as military spending is a cost of freedom. And of course society can attempt to reduce or make up for these costs through various means, not the least of which would be the cost savings ( $\$ 7.5-\$ 10$ billion annually, by some estimates) realized from ending the "war on drugs" against marijuana "offenders." See supra note 110. What about hard drugs like heroin, crack cocaine, etc.? The freedom of autonomy approach is open to (but not convinced by) the argument that there is a point at which the use and possession of those items is so demonstrably harmful to society as $a$ whole that government may legitimately prohibit them, in which case the means of dealing with the issue-whether through punishment, treatment, etc.--is a policy matter for the elected legislative body. On the other hand, whereas governments everywhere have erred on the side of paternalism even with marijuana, the freedom of autonomy principle is also open to-and on balance favors - the argument that because hard drugs are harmful to the using individual, not others, they should not be prohibited. They may be heavily regulated and controlled under this argument - but not prohibited. Government paternalism is not the answer-rather, education on the health dangers (as with tobacco) will help prevent people from using. This second argument has several advantages over the first: (1) it need not be concerned with the supremely difficult task in differentiating those substances so harmful as to be absolutely prohibited from those that are not; (2) it ameliorates many problems associated with prohibition, such as the violence associated with trafficking; (3) it adheres to the guiding principle of resolving any close calls in favor of the presumption of liberty-i.e., favoring individual freedom of autonomy, instead of government prohibition.

117. BAILYN, supra note 5, at v-vi.

118. LEVY, supra note 2, at 252. See supra notes 51-53 and accompanying text.

119. The contemporary arguments over abortion are well-documented, and we will not re-visit them here. At the core of the debate is a seemingly intractable disagreement: one side says life begins at conception; the other says it begins at birth (or perhaps viability), and never the twain shall meet. Each side is passionate in its views; neither hears what the other is saying-both talk past one another. 
Moreover, abortion is the hardest case of all because a choice must be made-indeed, a woman's postponing or avoiding action is itself an affirmative choice to have a baby.

For our purposes the question is who will make this decision? Will it be the government as proxy for the nascent life? Or rather will the woman be free to make this most difficult of decisions on her own behalf?

Applying freedom of autonomy principles, the answer is not automatic. To the extent that by prohibiting abortion the government is acting to protect the right of the zygote, embryo or fetus ${ }^{120}$ to be left alone on a matter of natural private concern (to live), it is acting legitimately. On the other hand, prohibiting abortion certainly does not leave a woman alone on a matter of private concern, and thus violates her individual freedom of autonomy.

But this assumes that fully-protected life begins at conceptionan assumption that a rational approach simply cannot make. The rights of a zygote, embryo or early fetus cannot be equated with those of a late-term fetus or an infant-the latter possess some measure of human consciousness, ${ }^{121}$ whereas a zygote, embryo or early fetus does not. The woman's freedom of autonomy must prevail at this early stage. When the fetus achieves viability - where it can survive on its own independently of the mother - the equation shifts. For freedom of autonomy purposes the fetus is a person at the point of viability, and the state is justified in prohibiting abortion to protect that person's right to be left alone to live, subject to the usual exceptions for mother's health and other extenuating circumstances.

This is the proper approach. For a solid five-plus months, before the fetus reaches viability, the woman's choice prevails. From viability onward, the fetus-person's choice, as enabled by government, prevails (subject to exceptions). The woman has a choice; once that choice is made she bears a responsibility. On this score, the Supreme Court has done an effective job of attempting to strike a reasoned balance between the competing interests by developing exactly this framework-before viability, government may not impose an "undue

120. A zygote is the "cell formed [at conception] by the union of two gametes"; an embryo is a "human organism in the first eight weeks from conception"; a fetus is "a human embryo of eight weeks or more." THE AMERICAN CENTURY DICTIONARY, (Warner Books Paperback ed.) (Oxford 1995).

121. "Consciousness" may be determined by measuring, for example, brain function or pain response. 
burden" on a woman's ability to have an abortion; after viability, the government is justified in restricting abortion, subject to exceptions. $^{122}$

Jed Rubenfeld offers as incisive a description as any on the inappropriateness of outright government prohibition of abortion:

It is impossible to name a single prohibitory law in our legal system with greater affirmative, [indeed] conscriptive, life-occupying effects than those imposed by a law forcing a woman to bear a child against her will. ['It compels this woman to bear a child. It forces motherhood upon her.'] This woman is physically taken over for a purpose dictated to her by the state, and this taking-over can be expected to last not merely nine months but for many years thereafter. Her body, her mind, and her time will be substantially occupied by the task that the state has forced upon her. She has been instrumentalized, impressed into state-dictated service. It is no exaggeration to say that a law forcing women to be mothers is a totalitarian intrusion into their lives. ${ }^{123}$

\section{Religion}

Recognition of the freedom of autonomy amendment would also reinforce other fundamental rights, some of which receive short shrift from the judiciary. For example, although the First Amendment guarantees the free exercise of religion, the Supreme Court currently allows government to prohibit free exercise with neutral, generally applicable laws that meet the less rigorous intermediate-scrutiny standard of review. Under the freedom of autonomy approach, free exercise may be subject to reasonable content-neutral time, place and manner restrictions, but they may not be prohibited outright except in the most exceptional cases in which the government overcomes the heavy presumption of invalidity and satisfies strict scrutiny standard of review. ${ }^{124}$

The Court's intermediate-scrutiny standard for generally applicable, neutral laws affecting free exercise was enunciated in Employment Division, Department of Human Resources of Oregon $v$. Smith $^{125}$ in $1990 .{ }^{126}$ Smith led to Congress's passage of the 1993 Re-

122. See Planned Parenthood v. Casey, 505 U.S. 833, 869-71 (1992). An "undue burden" is defined as a government action that places a "substantial obstacle" in the way of the woman in her efforts to get an abortion. Id. at 877.

123. RUBENFELD, supra note 70, at 225-26.

124. See supra note 90 and accompanying text.

125. 494 U.S. 872 (1990). 
ligious Freedom Restoration Act (RFRA), specifying "[g]overnment may substantially burden a person's exercise of religion only if it demonstrates that application of the burden to the person-(1) is in furtherance of a compelling government interest; and (2) is the least restrictive means of furthering that compelling governmental interest." ${ }^{127}$ In other words, any generally applicable, neutral law affecting the free exercise of religion shall be subject to strict scrutiny in the courts. $^{128}$ In 1997, the Court in turn struck down RFRA as beyond Congress's Fourteenth Amendment section Five scope of authority in City of Boerne v. Flores, ${ }^{129}$ stating that the Act, by telling the Court what standard of review to use in a particular case went beyond the mere enforcement of existing rights and instead created new substantive rights not given in the Fourteenth Amendment. ${ }^{130}$

For our purposes, the Court misses the boat in Smith and Boerne. Freedom of autonomy principles recognize the legitimate role of government in applying, under firm guidelines, reasonable contentneutral time, place and manner restrictions on individual liberty of free choice on matters of natural private concern, ${ }^{131}$ but require that any outright prohibition carry a heavy presumption of invalidity and must satisfy strict scrutiny review to survive. ${ }^{132}$ The Court does not

126. See id. at 885-90. Smith, a member of the Native American Church who was denied unemployment benefits from the state after being convicted for violating a state law prohibiting the use of hallucinogenic drugs, claimed that resulting denial of benefits constituted a violation of his free exercise rights. Id. at 874. The Court upheld Smith's conviction. Id. at 890 .

127. 42 U.S.C. $\S 2000 \mathrm{bb}-1$ (b) (1993). Smith and RFRA represent something of an ironic role-reversal, with the Court taking a less protective view of a freedom of autonomy right than Congress-here Congress seeks to protect the free exercise of religion from government interference (ironically still, it is an Act of Congress itself-i.e., punishing the use of soft drugs that constituted the government interference), and it is the Court that is less protective of the right. Congress thereafter amended its law to include an exception for use of peyote by Native Americans in tribal rituals. American Indian Religious Freedom Act Amendments of 1994, Pub. L. No. 103-344, 108 Stat. 3125 (1994) (codified at 42 U.S.C. § 1996a (2000)).

128. See 42 U.S.C. $\S 2000 \mathrm{bb}-1$ (b).

129. 521 U.S. 507 (1997). In Boerne, parishioners of a Catholic Church claimed that a municipality's denial of the Church's application for a zoning variance to build an addition onto its facilities constituted a violation of their free exercise rights. Id. at 511-12.

130. 521 U.S. at 529-34.

131. See supra notes 63-67, 87 and accompanying text, discussing the Court's analogous speech doctrine allowing the limiting regulations only if they offer reasonable content-neutral time, place or manner alternatives. These legitimate restrictions, of which there are many examples, are less objectionable precisely because they are limits, not outright prohibitions. The limits on free exercise, by contrast, offer no such alternative-Smith was prohibited outright from practicing his religion free of government recrimination. Smith, 521 U.S. at 890 .

132. See supra note 87 and accompanying text. 
distinguish in Smith and Boerne between government restrictions and prohibitions-it simply applies a blanket rule that any generally applicable, neutral rule gets intermediate scrutiny regardless of its prohibitory effect on free exercise. ${ }^{133}$ In Smith, the underlying neutral, generally applicable law created an outright prohibition on one's free exercise of religion, so it should have been strictly scrutinized; whereas the underlying neutral, generally applicable zoning decision by the city of Boerne in applying its local ordinance merely placed a place restriction on the church, so it was properly reviewed under intermediate scrutiny. ${ }^{134}$

On structural separation of powers grounds, Boerne was correctly decided. The Court was justified in holding that Congress exceeded its Fourteenth Amendment section 5 powers in attempting to dictate to the Court how it will exercise its power of judicial review. ${ }^{135}$ Congress cannot tell the judiciary substantively how to adjudicate cases, whereas the Constitution can ${ }^{136}$ And a reading of the Constitution true to its libertarian origins recognizes a broad right to freedom of autonomy. ${ }^{137}$

\section{Foundations}

To appreciate the American colonists' view of individual liberty, one must understand their own sense of history. They had come recently out of oppressive circumstances of government tyranny and had a visceral understanding of the dangers posed to individual liberty by unrestrained government. ${ }^{138}$ Their native land, England, through

133. See generally Smith, 494 U.S. 872; Boerne, 521 U.S. 507.

134. The city's denial of the zoning variance was a neutral "place" restriction. Whether it was a reasonable neutral time, place or manner restriction is another matter-maybe it was, maybe it was not, but that is a separate question.

135. See generally Boerne, 521 U.S. at 529-34.

136. See U.S. v. Klein, 80 U.S. 128, 147-48 (1871).

137. The First Amendment establishment clause, the structural support holding up Jefferson's strict wall of separation between church and state (protecting government from the influence of any particular religion, and also in "protecting my religion from government," as one colleague, Frank Ravitch, puts it), is under siege as well. The Court's two 2005 decisions regarding whether government may impose the majority's religious viewpoint on all citizens by allowing placement of religious paraphernalia on government property do not help - holding in one case that the Ten Commandments may stay on government grounds, and in the other case that the Ten Commandments may not stay on government grounds. See generally McCreary County, Ky v. ACLU of Ky, 125 S. Ct. 2722 (2005) (holding that Ten Commandments may not stay on government grounds); Van Orden v. Perry, 125 S. Ct. 2854 (2005) (holding that Ten Commandments may stay on government grounds).

138. See generally BAILYN, supra note 5 . 
the centuries had endured alternating episodes of royal despotism and commoner anarchy infringing upon liberty, with liberty most recently only narrowly emerging from its trials intact in what "had been a close victory which would require the utmost vigilance to maintain." 139 Elsewhere in the world, liberty had been lost. ${ }^{140}$

"It had been at this critical juncture in the history of England and of liberty," Bailyn writes, "that America had been settled. The conjunction had not been accidental. 'It was this great struggle that peopled America ... a love of universal liberty, and a hatred, a dread, a horror, of the infernal confederacy [of temporal and spiritual tyranny] projected, conducted, and accomplished the settlement of Amer-

139. See id. at 81 . In the minds of the colonists, among the primary reasons liberty was able to prevail in Britain was that:

[g]radually safeguards against such evils [threatening liberty] were built up-that great array of documents starting with Magna Carta that outlined the inner boundaries of English liberties-which remained effective until, in the seventeenth century, that "execrable race of the Stuarts" precipitated a "formidable, violent, and bloody" struggle between the people and the confederacy "of temporal and spiritual tyranny." In the end liberty, as all the world knew, had been re-established in England.

Id. at 81 (citing and quoting, e.g., James Otis, Rights of the British Colonies (JHL 7), p.31; Bland, Inquiry (JHL 17), pp. 7-8; Jefferson to Edmund Pendleton, August 13, 1776, Papers of Thomas Jefferson (Julian P. Boyd, ed., Princeton, 1950), I, 492; Hicks, Consideration (JHL 18) p. 2; James Wilson, Considerations on the ... Authority of the British Parliament (Philadelphia, 1774: JHL Pamphlet 44), p.12; Adams, Dissertation, in Works, III, 451).

140. BAILYN, supra note 5, at 79-80.

The colonists ... looked ahead with anxiety rather than with confidence, for they knew, from the whole of their received tradition, of the desperate plight of liberty everywhere: "new tyrannies have sprung up, like so many new plagues, within the memory of man, and ... [have] engrossed almost the whole earth," rendering "the world a slaughterhouse." Rulers of the East were "almost universally absolute tyrants .... The states of Africa are scenes of tyranny, barbarity, confusion, and every form of violence. And even in Europe, where human nature and society are arrived at the highest improvements, where can we find a well constituted government or a well governed people? France 'has an arbitrary authority'; Prussia, 'an absolute government'; Sweden and Denmark 'have sold or betrayed their liberties'; Rome 'groans under a medley of civil and ecclesiastical bondage'; Germany 'is a hundredheaded hydra'; and Poland a ruin of 'extravagant licentiousness and anarchy ... the nobility and gentry arbitrary despotic tyrants, and the populace a race of slaves."' Only in Britain - and her colonies - had liberty emerged from its trials in tact; only in Britain had the battle repeatedly been won. Yet even in Britain the margin of victory had been narrow, especially in the last, bitter struggle with would-be despots of the house of Stuart. And the dangers were known to persist.

Id. at 79-80. (alteration in original) (citing Cato's Letters, no. 73; New York Gazette: or, The Weekly Post Boy, November 1, 1756, (quoting at length "a survey of the kingdoms of the earth" that appeared in the eleventh essay by "Virginia-Centinel," originally published in the Virginia Gazette in September or October, 1756.)) For an almost identical account see the New York Mercury, May 22, 1758. 
ica." "141 The colonists' conception of threats to liberty throughout recent history therefore "was a matter of great importance... not merely because it illustrated the characteristic dangers liberty faced but also because it made clear their own special role in history." ${ }^{142}$

Revolutionary-era Americans themselves were aware that a fortuitous confluence of events had placed them at a unique crossroads in history, to the point where by 1776 "Americans had come to think of themselves as in a special category, uniquely placed by history to capitalize on, to complete and fulfill, the promise of man's existence."143 As John Adams put it in his diary, "The liberties of mankind and the glory of human nature is in their keeping. ... America was designed by Providence for the theatre on which man was to make his true figure, on which science, virtue, liberty, happiness, and glory were to exist in peace." 144

The view of America as a kind of unique Petri dish in time was shared by others outside of the colonies as well:

European illuminati continued to identify America, as John Locke had done, with something approximating a benign state of nature and to think of the colonies as special preserves of virtue and liberty. ... No less a figure than Voltaire stated [in 1734] that America was the refinement of all that was good in England, writing in his Lettres philosophiques that Penn and the Quakers had actually brought into existence "that golden age of which men talk so much and which probably has never existed anywhere except in Pennsylvania." 145

Over a period of a century and a half [before the founding], America became accustomed to the idea that government existed by consent of the governed, that the people created the government, that they did so by written compact, that the compact reserved their natural rights, and that it constituted a fundamental law to which the government was subordinate. Constitutionalism, or the theory of limited government, was in part an outgrowth of [this] social compact. ... To Americans, however, Parliament had ir-

141. BAILYN, supra note 5 at $82-83$.

142. Id. at 80 . "[T] $]$ he settlers of America had emigrated to create in a new land civil and ecclesiastical governments purer, freer than those they had left behind. The transplantation had been made from an undefiled branch of the nation, strong, healthy, brimming with the juices of liberty, and it had been placed in a soil perfect for its growth. In the colonies, 'sought and settled as an asylum for liberty, civil and religious'..." Id. at 83.

143. Id. at 20.

144. Id. (quoting John Adams, DIARY AND AUTOBIOGRAPHY, I, 282).

145. BAILYN, supra note 5 , at 83-84. 
revocably limited itself [in order to protect individual liberties] by reaffirmations of the Magna Carta and passage of the Petition of Right of 1628, the Habeas Corpus Act of 1679, the Bill of Rights of 1689 , and the Toleration Act of 1689. Americans learned that a free people are those who live under a government so constitutionally checked and controlled that its powers must be reasonably exercised without abridging individual rights. ${ }^{146}$

"A half-century before John Locke's Second Treatise on Government, Thomas Hooker of Connecticut expounded the social compact theory," 147 and one hundred years before the Declaration of Independence, the Pennsylvania "Charter of Fundamental Laws of West New Jersey (1677), which was probably the work of William Penn ... began with the provision that the "common law or fundamental rights' of the colon[ists] should be 'the foundation of the government, which is not to be altered by the Legislative authority.",148 This was a significant expansion over the protections offered in Mother England, where the "liberty documents ... limited only the crown, not the legislature."

"The Virginia constitution of 1776, the first permanent state constitution, began with a Declaration of Rights that restrained all branches of government... [ [and further specified that] 'all men' are equally free and have inherent rights that cannot be divested even by compact; that among these rights are the enjoyment of life, liberty, and property and the pursuit of happiness; and that all power derives from the people, who retain a right to change the government if it fails to secure its objectives." 149

The political philosophy of the pre-Revolutionary and Revolutionary generations comes through clearly in their writing, ${ }^{150}$ which

146. LEVY, supra note 2, at 3-4.

147. Id. at 3 .

148. Id. at 7 .

149. Id. at 7 .

150. Bailyn writes,

$[\mathrm{T}]$ he leaders of the American Revolution ... turned out ... a rich literature of theory, argument, opinion and polemic. Every medium of written expression was put to use. The newspapers ... were crowded with columns of arguments and counterarguments appearing as letters, official documents, extracts of speeches, and sermons. Broadsides - single sheets ... appeared everywhere; they could be found posted or passing from hand to hand in the towns of every colony. Almanacs... universally available in the colonies, carried ... a considerable freight of political comment. Above all, there were pamphlets: booklets consisting of a few printer's sheets, folded in various ways so as to make various sizes and numbers of pages, and sold-the pages stitched together loosely, unbound and uncovered. 
itself was influenced by a wide range of written sources, from the ancients, ${ }^{151}$ the European Enlightenment, ${ }^{152}$ to English common lawyers, ${ }^{153}$ to covenant theology, ${ }^{154}$ but "important as all of these clusters

BAILYN, supra note 5, at 1-2 (citing ARTHUR M. SCHLESINGER, PRELUDE TO INDEPENDENCE 215-16 (New York, 1958); Philip Davidson, PROPAGANDA AND THE AMERICAN REVOLUTION 216-24 (Chapel Hill, 1941)).

Explanatory as well as declarative, and expressive of the beliefs, attitudes, and motivations as well as the professed goals of those who led and supported the Revolution, the pamphlets are the distinctive literature of the Revolution. They reveal, more clearly than any other single group of documents, the contemporary meaning of that transforming event.

BAILYN, supra note 5 , at 8 .

151. Among the most conspicuous, but often somewhat superficial sources were the classical authors such as Homer, Sophocles, Plato, Euripides, Herodotus, etc. "It was an obscure pamphleteer indeed who could not muster at least one classical analogy or one ancient precept." Id. at 24 (quoting Charles F. Mullett, Classical Influences on the American Revolution, CLASSICAL JOURNAL 35, 93-94 (1939-40). Of the classics,

above all Cicero, Sallust, and Tacitus-writers who had lived either when the republic was being fundamentally challenged or when its greatest days were already past and its moral and political virtues decayed.... For the colonists, arguing the American cause in the controversies of the 1760's and 1770's, the analogies to their own times were compelling.... The classics of the ancient world are everywhere in the literature of the Revolution, but they are everywhere illustrative, not determinative, of thought.

BAILYN, supra note 5, at 25-26.

152. Bailyn writes,

More directly influential in shaping the thought of the Revolutionary generation were the ideas and attitudes associated with the writings of Enlightenment rationalism-writings that expressed not simply the rationalism of liberal reform but that of enlightened conservatism as well.... The ideas and writings of the leading secular thinkers of the European Enlightenment-reformers and social critics like Voltaire, Rousseau, and Beccaria as well as conservative analysts like Montesquieu-were quoted everywhere in the colonies, by everyone who claimed a broad awareness. ... Alexander Hamilton, seeking to score points against his venerable antagonist, Samuel Seabury, recommended with arch condescension that his adversary get himself at the first opportunity to some of the writings of Pufendorf, Locke, Montesquieu, and Bulamaqui to discover the true principles of politics.

Id. at 26-27. All of that said,

the knowledge they reflect, like that of the ancient classics, is at times superficial ... ; moreover, everyone, whatever his position on Independence or his judgment of Parliament's actions, cited them as authoritative; almost no one, Whig or Tory, disputed them or introduced them with apology.... [E]xcept for Locke's, their influence, though more decisive than that of the authors of classical antiquity, was neither clearly dominant nor wholly determinative.

Id. at 28-30.

153. "Also prominent and in certain ways powerfully influential was yet another group of writers and ideas ... the great figures of England's legal history, especially the seventeenthcentury common lawyers" like Sir Edward Coke; Lord Chief Justices Francis Bacon, Sir Matthew Hale, Sir John Vaughan, and Sir John Holt; and William Blackstone. 
of ideas were, they did not in themselves form a coherent intellectual pattern." 155 "What brought these disparate strands of thought together, what dominated the colonists' miscellaneous learning and shaped it into a coherent whole, was the influence of ... the writings of a group of prolific [seventeenth century English] opposition theorists," 156 as then modified, enlarged and fused into a whole by a group of early eighteenth-century writers-writers who were essentially "coffeehouse radicals and opposition politicians, spokesmen for the anti-Court independents within Parliament and the disaffected with-

The common law was manifestly influential in shaping the awareness [and serving as a repository of history and human dealings] of the Revolutionary generation ... [indeed, it] stood side by side with Enlightenment rationalism in [their] minds.... But again, it did not in itself determine the kinds of conclusions men would draw in the crisis of the time.

Id. at 30-31.

154. Another,

major source of ideas and attitudes of the Revolutionary generation stemmed ultimately from the political and social theories of New England Puritanism, and particularly from the ideas associated with covenant theology.... In one sense this was the most limited and parochial tradition ... [in that it was] restricted in its appeal to those who continued to understand the world, as the original Puritans had, in theological terms. But in another [ironic] sense it contained the broadest ideas of all, since it offered a context for everyday events nothing less than cosmic in its dimensions.... [It was] found everywhere in the eighteenth-centruy colonies, [and] stimulated confidence in the idea that America had a special place, as yet not fully revealed, in the architecture of God's intent.

Id. at 32-33.

155. Bailyn writes,

There were among them, in fact, striking incongruities and contradictions. The [English] common lawyers the colonists cited, for example, sought to establish right by appeal to precedent and to an unbroken tradition evolving from time immemorial, and they assumed ... inherited custom, contained within it a greater wisdom than any man or group of men could devise by the power of reason. Nothing could have been more alien to the Enlightenment rationalists whom the colonists also quoted - and with equal enthusiasm. These theorists felt that it was precisely the heavy crust of custom that was weighing down the spirit of man; they sought to throw it off and to create by the unfettered power of reason a framework of institutions superior to the accidental inheritance of the past.

BAILYN, supra note 5, at 33-34.

156. Prolific writers, these:

"country" politicians and publicists... [were] united in criticism of "court" and ministerial power... [and included among their numbers] John Milton, author of Eikonoklastes and The Tenure of Kings and Magistrates (both published in 1649) ... the like-minded Henry Neville; [and,] above all . . the doctrines of Algernon Sidney, that "martyr to civil liberty," whose Discourses Concerning Government (1698) became, in Caroline Robbins' phrase, a "textbook of revolution" in America.

Id. at 34-35 (citations omitted). 
out.... [This group] faded subsequently into obscurity and are little known today. But more than any other single group of writers they shaped the mind of the American Revolutionary generation."157

The most influential of these "intellectual middlemen [to the colonists] were those spokesmen for extreme libertarianism, John Trenchard (1662-1723) and Thomas Gordon (d.1750)."158 Together with the treatises of John Locke, ${ }^{159}$ the writings of Trenchard and Gordon "ranked [to the colonists] . . . as the most authoritative state-

157. Id.

158. Id. at 34-35. Trenchard and Gordon, joined forces to produce, first, the weekly Independent Whig to attack High Church pretensions and, more generally, the establishment of religion, fifty-three papers of which were published in book form in 1721; and Cato's Letters, a searing indictment of eighteenth-century English politics and society ... which appeared first serially in The London Journal and then, beginning in 1720, in book form . . . . [T] hese libertarian tracts ... left an indelible imprint on the "country" mind everywhere in the English-speaking world. In America, they were republished entire or in part again and again, "quoted in every colonial newspaper from Boston to Savannah," and referred to repeatedly in the pamphlet literature.

$I d$. at 36. The ideas forwarded by Trenchard and Gordon-ideas "based on extreme solicitude for the individual and an equal hostility to government, were expressed in a spirit of foreboding and fear for the future." Id. at 48.

159. Bailyn writes,

In Locke's formulation, natural law dictates that man is subject to divine imperatives to live in certain ways, but, within the limits set by the law of nature, men can act in a godlike fashion. Man as maker has a maker's knowledge of his intentional actions, and a natural right to dominion over man's products. Provided we do not violate natural law, we stand in the same relation to the objects we create as God stands to us; we own them just as he owns us.

BAILYN, supra note 5, at 48 (citing John Locke, An Essay Concerning Human Understanding, Book II, Chapter 27 and Book I, Chapter 30; JAMES TUlLY, A DISCOURSE ON PROPERTY: JOHN LOCKE AND HIS ADVERSARIES, 108-10, 121 (Cambridge: Cambridge University Press, 1980)); see also Levy, supra note 2, at 3 (stating that for the founders, "the predominance of [Lockean] social compact theory reflected a condition of freedom and, like the experience with charters, contributed to the belief in written bills of rights"). Shapiro sums up,

Natural law, or God's natural right, thus sets outer boundaries to a field within which humans have divine authority to act as miniature gods, creating rights and obligations of their own.... [Locke insisted] that God speaks directly to every individual who reads the Scriptures, and that no human authority is entitled to declare one interpretation authoritative in the face of a conflicting one. This freedom to comprehend natural law by one's own lights supplied the basis of Locke's right to resist that could be invoked against the sovereign, and to which he himself appealed when opposing the English crown during the 1680s. His conviction that right answers can be discovered about the meaning of the Scriptures, and, hence, what natural law requires, was not understood to obliterate human freedom to disagree even about that very subject.

SHAPIRO, supra note 18 , at 15-17 (citing JOHN LOCKE, TwO TREATISES OF GOVERNMENT (London: Allen \& Unwin, 1986)). 
ment of the nature of political liberty and above Locke as an exposition of the social sources of the threats it faced."160 "Standing with Trenchard and Gordon as early eighteenth-century 'preceptors of liberty' was the liberal Anglican bishop, Benjamin Hoadly[, the] 'best hated clergyman of the century amongst his own order,'... [who] was widely held to be one of the notable figures in the history of political thought." 161

In short, "[o]pposition thought, in the form it acquired at the turn of the seventeenth century and in the early eighteenth century, was devoured by the colonists. From the earliest years of the century it nourished their political thought and sensibilities.... By 1728, in fact, Cato's Letters had already been fused with Locke, Coke, Pufendorf, and Grotius to produce a prototypical American treatise in defense of English liberties overseas, a tract indistinguishable from any number of publications that would appear in the Revolutionary crisis fifty years later."162 "Testimonies to the unique influence of this op-

160. BAILYN, supra note 5, at 36 .

161. Bailyn writes,

For illustrations of the way Hoadly's ideas entered into the mainstream of American Revolutionary thought, see Jonathan Mayhew's Discourse Concerning Unlimited Submission (Boston, 1750: JHL Pamphlet 1)... . Similarly, an anonymous English writer at the end of the century attributed the origins of the French Revolution to the fact that "every class of Frenchman ... became familiarly acquainted with Sidney, Locke, and Hoadly." An Historical View of the French Revolution . . . . (Newcastle upon Tyne, 1796), p. 18.

Id. at 37-38.

With Hoadly, among his contemporaries, though below him in importance to the Americans, was the outstanding opponent in Parliament of [Robert] Walpole's administration, the leader of a coterie of early eighteenth-century freethinking Whigs, Robert Viscount Molesworth. Friend of Trenchard and Gordon, encomiast of Cato's Letters (they were frequently attributed to him), he was known particularly in the colonies for his Account of Denmark (1694), which detailed the process by which free states succumb to absolutism. An opposition leader of another sort who contributed in a more complicated way to the colonists' inheritance of early eighteenth-century thought was the spectacular Jacobite politician, writer, and philosopher, Henry St. John, Viscount Bolingbroke. His Craftsman, appearing weekly or semiweekly for a full ten years, from 1726 to 1736 , roasted Walpole's administration in crackling fires of ridicule and denunciation ... and decried the corruption of the age and warned of the dangers of incipient autocracy ... [A]mong the many Whig historians the Americans knew and referred to ... their preference was for the exiled Huguenot, Paul de Rapin-Thoyras ... [whose works,] published in English between 17[17] and $1731 \ldots$ provided indisputable proof of the theories of all of the radical and anti-establishment writers by demonstrating their validity through a thousand years of English history.

Id. at 41-42. (citations omitted).

162. Id. at 43 (citing Daniel DUlanY, SR., THE Right OF THE INHABITANTS OF 
position literature ... are everywhere in the writings of eighteenthcentury America."163 "Above all, their influence may be seen in the way the peculiar bent of mind of the writers in this tradition was reflected in the ideas and attitudes of the Americans .... "Their key concepts - natural rights, the contractual basis of society and government, the uniqueness of England's liberty-preserving 'mixed' constitution-were commonplaces of the liberal thought of the time. ${ }^{164}$ But if the elements of their thought were ordinary, the emphasis placed upon them and the use made of them was not." 165

Revolutionary-era lawyer John Dickinson epitomized these commonly-held views of the day, writing: "[Natural rights] are created in us by the decrees of Providence, which establish the laws of our nature. They are born with us; exist with us; and cannot be taken from us by any human power without taking our lives. In short, they are founded on the immutable maxims of reason and justice.... The natural absolute personal rights of individuals are ... the very basis of all municipal laws of any great value. [Indeed,] Magna Carta itself is in substance but a constrained declaration, or proclamation and promulgation in the name of King, Lords, and Commons of the sense the latter had of their original, inherent, indefeasible, natural rights." 166

MARYLAND TO THE BENEFIT OF THE ENGLISH LAWS (1728), reprinted in ST. GEORGE L. SIOUSSAT, THE ENGLISH STATUTES IN MARYLAND (Baltimore 1903)).

163. Id. at 44-45. Bailyn writes,

Sometimes they are explicit, as when Jonathan Mayhew wrote that, having been "initiated, in youth, in the doctrines of civil liberty, as they were taught by such men ... as Sidney and Milton, Locke, and Hoadly, among the moderns, I liked them; they seemed rational"; or when John Adams insisted, against what he took to be the massed opinion of informed Englishmen, that the root principles of good government could be found only in "Sidney, Harringon, Locke, Milton, Nedham, Nevill, Burnet, and Hoadly"; or again, when he listed the great political thinkers of 1688 as "Sidney, Locke, Hoadly, Trenchard, Gordon, Plato Redivivus [Neville]." More often, the evidence is implicit, in the degree to which the pamphleteers quoted from, plagiarized, and modeled their writings on Cato's Letters and The Independent Whig.

Id.

164. Id. at 45.

165. Id. at 44-45. For example, "John Adams professed to have read through five times [Bolingbroke's Works]." Id. at 39 n.22.

166. Id. at 77-78 (quoting "[John Dickinson], An Address to the Committee of Correspondence in Barbados ... . (Philadelphia, 1766), in Paul L. Ford, ed., The Writings of John Dickinson (Memoirs of the Historical Society of Pennsylvania, XIV, Philadelphia, 1895), p.262) ..." Id. at 78 n.22. See also Levy, supra note 2, at 3. Bailyn notes that Dickinson reflects the prevailing view among the colonists was that "[s]uch God-given, natural, inalienable rights, distilled from reason and justice through the social and governmental compacts, were expressed in the common law of England, in the statutory enactments of Parliament, and 
The mere seven decades between the birth of the federal constitutional democracy in 1789 and the onset of the Civil War in 1861 saw a sea-change in attitude regarding the nature of the governmental threat to individual liberty. As noted by Professor Amar, in the 1780s the states were regarded as benign; indeed, they were regarded as protectors against a threatening national government. ${ }^{167}$ As we have seen, "[i]n light of their experience with imperial arrogance and oppression on the one hand, and the heroic roles played by local governments in resisting oppression on the other, many Americans in the 1780 s associated strong central government with tyranny and a strong state government with freedom." 168 But after the turn of the century, "it would be hard to argue that the central government acted qualitatively more repressively than local ones." 169 "The structural imperatives of the peculiar institution [of slavery] led slave states to violate virtually every right and freedom declared in the Bill-not just the rights and freedoms of slaves, but of free men and women too.",

in the charters of privileges promulgated by the crown." BAILYN, supra note 5 at 77-78.

167. AMAR, supra note 7, at 159 (citing GORDON S. WOOD, THE CREATION OF THE AMERICAN REPUBLIC 24-25, 60-61, 362 (1776-1787) (1969); GORDON S. WOOD, THE RADICALISM OF THE AMERICAN REVOLUTION 104 (1991); citing also Del. Declaration of Rights of 1776, art. 6 ("the right of the people to participate in the Legislature, is the foundation of liberty and of all free government"); Md. Const. of 1776 (Declaration of Rights), art. V).

168. Id. at 158 .

The American Revolution had featured local colonies fighting an imperial center in the name of both freedom and federalism.... This association was of course strengthened by the events in the following decade, with the Virginia and Kentucky legislatures [ghostwritten by Madison and Jefferson, respectively] leading the charge against the federal Sedition Act.

Id.

169. Id. at 159. No issue:

place[d] the libertarian track record of federal versus state governments in stronger light than did slavery. And on this question, states did not shine. Slavery was almost exclusively a creature of state law.... [A] major platform of the Free Soil and Republican Parties in the 1840s and 1850s was that the Constitution frowned on federal involvement with slavery. Freedom was national, slavery local-hence the popular slogan, "Freedom National," a slogan that would have sounded quite odd in the 1780 s and 1790 s.

Id. at 160 (citing, NATIONAl PARTY PlatFoRMS, 1840-1968, 5 (Kirk H. Porter and Donald Bruce Johnson eds., 3d. 1966) (Liberty Platform of 1844, sec. 10, 11); ERIC FONER, FREE SOIL, FREe LABOR, FREE MEN 73-102 (1970); HAROLD M. HYMAN AND William M. WIECEK, EQUAL JUSTICE UNDER LAW 17-18, 92-93, 170 (1982)).

170. Id. at 160 (citing e.g., CURTIS, supra note 7 at 36; WILlIAM Goodell, THE AMERICAN SLAVE CODE IN THEORY AND PRACTICE 372-84 (Negro Universities Press, 1968) (1853); TENBROEK, infra note 174, at 38-39, 125-26; H. HYMAN and W. WIECEK, supra note 169 at 15, 182-83, 280-81, 401-02) "Slavery bred repression." Id. at 280-81 (citing CoNG. 
Add to the slave states' abuses the Court's narrow textual interpretation in the 1833 case Barron v. Baltimore $e^{17 !}$ that the Bill of Rights applies only to Congress, not the states, and you have a ready source of conflict between the prevailing judicial doctrine of the day and the founders' original position that the Constitution protects natural individual liberties. ${ }^{172}$ "To a nineteenth-century believer in natural rights, ${ }^{173}$ the Bill was not simply an enactment of We the People as the Sovereign Legislature bringing new legal rights into existence, but rather a declaratory judgment by We the People as the Sovereign High Court that certain natural or fundamental rights already existed." Barron failed to reflect this view.

GLOBE, 36th Cong., 1st Sess. 2595-2602 (1860) (remarks of Sen. Charles Sumner); Michael Kent Curtis, The 1859 Crisis Over Hinton Helper's Book, The Impending Crisis: Free Speech, Slavery, and Some Light on the Meaning of the First Section of the Fourteenth Amendment, 68 CHI.-KENT L. REV. 1113, 1127, 1132 (1993)). "Speech and writing critical of slavery, even if plainly religious or political in inspiration, was incendiary and had to be suppressed in southern states, lest slaves overhear and get ideas." Id. (citing CURTIS, supra note 7 at 23, 30-38; KENNETH M. STAMPP, THE PECULIAR INSTITUTION 211-12 (1956); Alfred Avins, Incorporation of the Bill of Rights: The Crosskey-Fairman Debates Revisited, 6 HARV. J. ON LEGIS., 1726 (1968); Clement Eaton, THE Freedom OF ThOUght StRugGle IN THE Old SOUTH (1964); RUSSELl B. NYE, FETTERED FREEDOM (1963)). "In 1859 a Virginia postmaster even banned the New York Tribune, a leading Republican newspaper, under a sweeping state censorship statute; twenty years earlier, the state had tried to prosecute citizens for circulating an antislavery petition to Congress." AMAR, supra note 7, at 160-61 (citing CURTIS). Quite a fall indeed in a few short decades for the proud state of Virginia, home of Washington, Jefferson, and Madison. "Teaching slaves to read (even the Bible) was a criminal offense punished severely in some states." Id. at 161 (citing e.g., CONG. GLOBE, 39 $9^{\text {th }}$ Cong., 1st Sess. 1013 (1866) (remarks of Rep. Tobias Plants); K. STAMPP, supra, at 208, 22; TENBROEK, supra, at 124-25). "[I]n at least one state, writing, printing, publishing, or distributing abolitionist literature was punishable by death." Id. (citing Kurt. T. Lash, The Second Adoption of the Free Exercise Clause: Religious Exemptions Under the Fourteenth Amendment, 88 Nw. U. L. REV. 1106, 1134,1134 n.127 (1994)).

171. 32 U.S. 243 (1833).

172. In failing to honor the founders' views regarding individual liberties as inviolable natural law, Barron's underlying message was that Bill of Rights provisions such as the First Amendment were "merely an interpretation of the positive-law code of the original Constitution, declaring that Congress lacked Article I, section 8-enumerated power to regulate religion in the states or to suppress speech." AMAR, supra note 7, at 148-49.

173. Following Barron, it was left to lawyers practicing "the common-law method in mid-nineteenth-century America ... [to find that] even if the federal Bill of Rights did not, strictly speaking, bind the states of its own legislative force ... [it was] at least declaratory of certain fundamental common-law rights. ." Id. at 147.

174. Id. at 148 (citing, e.g., JACOBUS TENBROEK, EQUAL UNDER LAW 90-91, 128 (Collier, 1965) (1951) ("[e]arly amendments [were] seen by [Barron] contrarians as 'declaratory constitutional safeguards of natural rights' and 'a meeting ground of constitutional and natural rights"'); Howard Jay Graham, Our "Declaratory" Fourteenth Amendment, 7 STAN. L. REV. 3, 3-4 (1954) (noting centrality of eighteenth- and nineteenth-century conception of various constitutional provisions as 'declaratory'); WILliam E. NELSON, THE FOURTEENTH 
The philosophical debate concerning the constitutional interplay of state and federal government with protection of natural individual liberties that took place in the first half of the nineteenth century set the stage after the Civil War for the Fourteenth Amendment's memorialization of the notion that the Constitution incorporates the Bill of Rights to apply to the states ${ }^{175}$ and implicitly protects natural rights. During the debate in the thirty-ninth Congress over the language for what became the Fourteenth Amendment, Section 1's principal draftsman John Bingham "made himself abundantly clear. Over and over he described the privileges-or-immunities clause as encompassing 'the bill of rights' - a phrase he used more than a dozen times in a key speech on February 28."176 Moreover, when asked again several

AMENDMENT 59 (1988) (quoting 1867 Pennsylvania legislator who described constitutional amendments as submitted to the people "sitting as a jury-that is, a judicial body"); 1 WILLIAM BLACKSTONE, COMMENTARIES 42, 53-55, 57-58, 86; BAILYN, supra note 5, at 69 , n.13, 78, 187-98 (1967); GORDON S. WOOD, THE CREATION OF THE AMERICAN REPUBLIC, 1776-1787, 294 (1969); Suzanna Sherry, The Founders Unwritten Constitution, 54 U. CHI. L. REV. 1127, 1132-33 (1987); Suzanna Sherry, Natural Law in the States, 61 U. CIN. L. REV. 171 (1992). State courts, through these approaches, saw their way clear to imposing principles distilled from the Bill of Rights within their own jurisdictions. AMAR, supra note 7, at 149-51 (citing Jones v. Robbins, 74 Mass. (8 Gray) 329, 340 (1857) ("[T] stitution of the United States, in the nature of a bill of rights, [should be regarded] as the annunciation of great and fundamental principles, to be always held in regard, both morally and legally, by those who make and those who administer the law [rather than as mere] precise and positive directions and rules of action."); Gardner v. Trustees of Newburgh, 2 Johns. Ch. 162, 165-68 (N. Y. 1816) (applying "just compensation" requirement despite absence of state mandate "after canvassing the 'soundest authorities' of Grotius, Puffendorf, and Blackstone, and the express language of [several neighboring states'] constitutions, [the judge] proclaimed: 'But what is of higher authority, and is absolutely decisive of the sense of the people of this country, [the principle] is made a part of the Constitution of the United States").

Similarly, the Georgia Supreme Court (ironically, given the antebellum era) was a leader in enunciating natural law: "The Bill of Rights' purpose 'was to declare to the world the fixed and unalterable determination of our people, that these invaluable rights ... should never be disturbed by any government.' The Bill was 'our American Magna Carta.'” Id. at 155 (quoting Campbell v. State, $11 \mathrm{Ga}$. 353, 367-68 (1852)).

175. The northern Republicans' disapproval of the southern states' practice of disarming of blacks in the South, as discussed in the debates over the Act, "fed the determination of northern Republicans to provide national enforcement of the Bill of Rights." It is fair to say that "[t]he efforts to disarm the freedmen were in the background when the 39th Congress debated the Fourteenth Amendment ...." ROBERT J. COTTROL \& RAYMOND T. DIAMOND, THE SECOND AMENDMENT: TOWARD AN AFRO-AMERICANIST RECONSIDERATION (1991), Reprinted in GUN CONTROL AND THE CONSTITUTION SOURCES AND EXPLORATIONS ON THE SECOND AMENDMENT 345-46 (Paul Finkelman ed. Garland Publishing, Inc., 1993).

176. AMAR, supra note 7, at 182 (citing CONG. GLOBE, $39^{\text {th }}$ Cong., $1^{\text {st }}$ Sess. $1088-94$ (1866)). In this speech "he also explained why a constitutional amendment was necessary, citing by name and quoting from the Supreme Court's opinions in Barron and one of its progeny, Livingston v. Moore." Id. (citing CONG. GLOBE, $39^{\text {th }}$ Cong., $1^{\text {st }}$ Sess. at 1089-90). "The day before, a colleague of Bingham's, Robert Hale, had suggested that states were already 
years later after the ratification of the Fourteenth Amendment, in 1871 , to clarify the amendment, "here, too, he immediately linked 'the privileges and immunities of citizens of the United States' with the Bill of Rights: "[T]he privileges and immunities of citizens of the United States, as contradistinguished from citizens of a State, are chiefly defined in the first eight amendments to the Constitution of the United States. Those eight amendments are as follows. [Bingham then proceeded to read the first eight amendments word for word.] These eight articles I have shown never were limitations upon the power of the States, until made so by the Fourteenth Amendment."177

bound by the Bill of Rights." Id. (citing CONG. GLOBE, $39^{\text {th }}$ Cong. $1^{\text {st }}$ Sess. at 1064), but Bingham set Hale and others straight with the following quotation from Livingston: "As to the amendments of the Constitution of the United States, they must be put out of the case, since it is now settled that those amendments do not extend to the States...' Id at 182-83 (citing CONG. GLOBE, $39^{\text {th }}$ Cong., $1^{\text {st }}$ Sess. at 1090 (quoting Livingston v. Moore, 32 U.S., (7 Pet.) $469,551-52$ (1833)). "Six weeks later Bingham again held forth on the need for his amendment, invoking 'the bill of rights' six times in a single speech and again reminding his colleagues that it 'has been solemnly ruled by the Supreme Court of the United States' that 'the bill of rights ... does not limit the powers of States." Id. at 183 (citing CONG. GLOBE, $39^{\text {th }}$ Cong., $1^{\text {si }}$ Sess. at 1291-93). In a speech in January 1867 , while the amendment was pending in the states, Bingham again reminded his audience that his amendment would overrule Barron. Id. at 183 (citing CONG. GLOBE, $39^{\mathrm{TH}}$ Cong., 2d. Sess. at 811 (1867)). Bingham had earlier stated, in 1859, that "whenever the Constitution guaranties to its citizens a right, either natural or conventional, such guarantee is in itself a limitation upon the States." Id. at 181 (citing CONG. GLOBE, $35^{\text {th }}$ Cong., 2d Sess. at 982 (1859). Moreover, "no state could violate the Constitution's 'wise and beneficent guarantees of political rights to the citizens of the United States, as such, and of natural rights to all persons, whether citizens or strangers." Id. at 182 (citing CONG. GLOBE, $35^{\text {th }}$ Cong., $2 d$ Sess. at 983 ).

177. AMAR, supra note 7 , at 183 (quoting CONG. GloBE, $42^{\text {nd }}$ Cong., $1^{\text {st }}$ Sess. 84 app. (1871)). Thaddeus Stevens, political leader of the House and head of the House delegation of the Committee on Reconstruction that officially reported the Fourteenth Amendment, stating:

shortly before the amendment came before the House for final approval . . . . "I can hardly believe that any person can be found who will not admit that every one of these provisions [in section 1 of the Fourteenth Amendment] is just... . But the Constitution limits only the action of Congress, and is not a limitation on the States. This amendment supplies that defect."

Id. at 185 (quoting CONG. GlOBE, $39^{\text {th }}$ Cong., $1^{\text {st }}$ Sess. $2459(1866)$ ). Two years earlier, in 1864 ,

Representative James Wilson had made clear that he too understood the "privileges and immunities of citizens of the United States" to include the guarantee of the amendments ... "Freedom of religious opinion, freedom of speech and press, and the right of assemblage for the purpose of petition belong to every American citizen.... With these rights no State may interfere.... Sir I might enumerate many other constitutional rights of the citizen which slavery has disregarded and practically destroyed, but I have [said] enough to illustrate my proposition: that slavery ... denies to the citizens of each State the privileges and immunities of citizens."

Id. at 184-85 (citing CONG. GLOBE, $38^{\text {th }}$ Cong., $1^{\text {st }}$ Sess. 1202-03 (1864)); Representative Hale 
But the Fourteenth Amendment privileges and immunities clause encompassed more than just the Bill of Rights-indeed, it was intended to provide constitutional cover for a full range of natural individual liberties, which had been neglected and abused between the time of founding and the Civil War (but this time mostly by state, rather than federal, government). ${ }^{178}$ This was in Reconstruction-era Americans' keeping, much like their Revolutionary-era ancestors, with the core belief in the existence of "absolute rights inherent in the people ... of which no power can legally deprive them ... principles which lie at the very foundation of civil liberty, and are most inti-

stating:

[T] hese amendments to the Constitution, numbered from one to ten ... constitute the bill of rights, a bill of rights for the protection of the citizen, and defining and limiting the power of Federal and State legislation .... [T] here is much force in the reasoning that there has been from first to last, a violation of the provisions in this bill of rights by the very existence of slavery itself.

CONG. GLOBE, $39^{\text {th }}$ Cong., $1^{\text {st }}$ Sess. 1064-65 (1866). In the Senate, head of the Joint Committee on Reconstruction Jacob Howard commented, "The great object of the first section of this [fourteenth] amendment is ... to restrain the power of the States and compel them at all times to respect these great fundamental [bill of rights] guarantees." AMAR, supra note 7, at 186 (quoting CONG. GLOBE, $39^{\text {th }}$ Cong., $1^{\text {st }}$ Sess. 2765-66 (1866)). Amar notes further that "the leading scholarly work counts no fewer than thirty Republican statements in the Thirty-eighth and Thirty-ninth Congresses voicing [similar] contrarian sentiments, and not one supporting Barron." Id. at 186 (citing MiCHAEL KeNT CuRTIS, No STATE Shall ABridgE: THE FOURTEENTH AMENDMENT AND THE BILL OF RIGHTS 112 (1986)). The comments of all of the Congressmen cited received broad media and public attention, yet

not a single person in either house spoke up to deny these men's interpretation of section I. Surely, if the words of section I meant something different, this was the time to stand up and say so. Consider, finally, that all of these men offered glosses that mesh perfectly with each other and, most importantly, with the plain meaning of the words of section $\mathrm{I}$.

Id. at 187. As Amar notes, "In light of all of this, it is [indeed] astonishing that some scholars, most notably Charles Fairman and Raoul Berger, have suggested that when Bingham invoked 'the bill of rights,' he didn't mean what he said." Id. at 183 (citing Charles Fairman, Does the Fourteenth Amendment Incorporate the Bill of Rights?, 2 STAN. L. REV. 26, 33-34, 134, 136 (1949); RAOUL BERGER, GOVERNMENT BY JUDICIARY 141-42 (1977); Raoul Berger, Incorporation of the Bill of Rights in the Fourteenth Amendment: A Nine-Lived Cat, 42 OHIO ST. L.J. $435,463(1981))$. "For a powerful rebuttal to the general claims of Berger's article, see Michael Kent Curtis, Further Adventures of the Nine-Lived Cat: A Response to Mr. Berger on Incorporation of the Bill of Rights, 43 OHIO ST. L.J. 89 (1982))." Id.

178. The Bill of Rights in its entirety serves to enumerate only a portion of those fundamental "rights," "liberties," "privileges," and "immunities" that the Fourteenth Amendment framers in the thirty-ninth Congress intended to incorporate to apply to the states. The reason the framers did not simply state clearly that the entire Bill of Rights was incorporated, Bingham says, was because they intended also to include other important freedoms found in the Constitution outside of the Bill of Rights, such as the privilege of the writ of habeas corpus found in Article I, Section 9. See, e.g., Amar, Akhil Reed, The Original Meaning of the Fourteenth Amendment, 19 HARV. J. L. \& PUB. POL'Y 443 (1996). 
mately connected with the dearest rights of the people.... [These p]rinciples ... deserve to be diligently taught to our children, and to be written upon the posts. of the houses, and upon the gates."179

With the constitutional complement now in place after Reconstruction, fast forward to the America of the early twenty-first century ${ }^{180}$ - where oppressive amendments discriminating against samesex couples are passed in all thirteen states where the question is on

179. AMAR, supra note 7, at 153 (quoting Holmes v. Jennison, 39 U.S. (14 Pet.) 540, 555-57 (1840) (C.P. VanNess argument)). Abolitionists and Republicans in the post-Civil War Congress viewed the Reconstruction Amendments as having an even more vital purpose: "In short, the Reconstruction Amendments would be interpreted as embodying the spiritual and moral principles undermined by the original Constitution." Rhonda V. Magee Andrews, The Third Reconstruction: An Alternative to Race Consciousness and Colorblindedness in Post-Slavery America, 54 ALA. L. REV. 483, 496 (2003). Professor Magee Andrews continues,

the historical record suggests that the framers of radical abolitionist constitutionalism, whose ideas would ultimately create the basis of Section One of the Fourteenth Amendment-men like Frederick Douglass, Charles Olcott, James Birney (a reformed ex-slaveholder himself), and Alvan Stewart [-as well as "other well-known intellectuals of the day, such as Emerson and Thoreau"-] looked toward a world which, in the century following the end of slavery, would be truly transformed... [and] imagined a world in which, in the first instance, humanity would be highly valued, supported, and protected by the state... [F]or many, the debasement of moral principle represented by the Constitution's sanction of slavery undermined the spiritual foundation of the new country: It broke the country's spirit. It follows, then, that the constitutional codification of our commitment to abolition would be seen as giving back what the slavery compromises took away: they were to mend the country's spirit.

Id. at 501 (citing Frederick DOUGLaSS, AN AMERICAN SLAVE, WRITTEN BY HIMSELF 4345, 296, 66-72 (Signet 1st ed., 1968)).

180. Regarding the peoples' trust in state as opposed to federal government, Professor Gardner suggests, "[t]rust in state governments enjoyed a resurgence during the late Nineteenth Century, particularly after public opinion turned against the northern occupation of the South and the Union programs of Reconstruction." Gardner, supra note 45, at 1009 (citing ERIC FONER, RECONSTRUCTION: AMERICA'S UNFINISHED REVOLUTION, 1863-1877 582 (1988); FORREST MCDONALD, STATES' RIGHTS AND THE UNION: IMPERIUM IN IMPERIO, 1776-1876 208-21 (2000); MELVIN I. UROFSKY \& PAUL FINKELMAN, A MARCH OF LIBERTY: A CONSTITUTIONAL HISTORY OF THE UNITED STATES 477 (2002)). "The Progressive reform movement of the early Twentieth Century, followed quickly by the Great Depression, two world wars, and the Civil Rights Movement, set the nation on a path in which national power was typically far more respected and trusted than state power." Id. (citing Keith E. Whittington, Dismantling the Modern State? The Changing Structural Foundations of Federalism, 25 HASTINGS CONST. L.Q. 483, 500-03 (1998)). "By the 1980s, however, resentment against national power seemed to rise once again." Id. at 503-22. Today, we may well live in an age in which the people are as close to true indifference between national and state power as they have ever been, and are willing to contemplate the exercise of power by either level of government, depending upon which level can more persuasively demonstrate that it can do the better job. Id. at 1010 (citing Linda Greenhouse, Will the Court Reassert National Authority?, N.Y. TIMES, at 4:14, Sept. 30, 2001). 
the ballot; where compassionate end-of-life choice is illegal in 49 states and where the one state where it is legal is being sued by the U.S. government asking the Supreme Court to declare the state law unlawful; where hundreds of thousands are criminally arrested annually (about 734,000 per year) and tens of thousands are in prison for possessing or using marijuana and the federal government successfully sues to prevent a state from allowing the compassionate medical use of marijuana; where a woman's right to maintain control over her own reproductive decisions hangs by a thread; and where religious freedom is under relentless attack. How did this happen? That the privileges and immunities clause was strangled in its crib by the Court in the 1873 Slaughterhouse Cases opinion, ${ }^{181}$ thus withholding from the judiciary a valuable tool for the protection of individual liberties for the following 125 years, certainly did not help matters; but more generally Americans themselves have not been vigilant enough in protecting their natural freedom of autonomy from a "wholly new species of oppression ... [where] the democratic government, acting in response to the will of the majority ... create[s] a society with a network of ... [rules] that none can escape." ${ }^{182}$ Now is the time for change.

\section{Reviving Freedom of Autonomy}

Professor Elizabeth Price Foley writes, "Instead of a land of individual liberty and ... tolerance, America has become a land of public morality and intolerance, all without the benefit of constitutional amendment... [and w] hile there is nothing wrong with having an opinion based upon one's culture or religion, there is something wrong with imposing this opinion upon others in a pluralistic society founded upon individual liberty."

181. 83 U.S. (16 Wall.) 36 (1873) (holding that the Fourteenth Amendment privileges and immunities clause refers only to the limited rights of "federal" citizenship, not to the more expansive rights of "state" citizenship). See, e.g., LAWRENCE, supra note 38.

182. See supra note 20 and accompanying text.

183. Foley, ElizabeTH PRICE, Liberty for All: PrIVACY VERSUS MORALITY IN THE AMERICAN CONSTITUTION (forthcoming Yale Press 2006) (manuscript at 62, 67-68, on file with author). Foley systematically describes how conventional or traditional governmental approaches to various cultural institutions and customs (for example, marriage, reproductive freedom, religion, etc.) deny specific fundamental liberties, and in so doing proves her point that "Americans have long forgotten the foundational constitutional principles of limited government and residual individual liberty" (manuscript at 26). 
That's the problem in a nutshell. It would be one thing had American government undertaken to micro-manage our lives and to infringe upon our natural rights of freedom of autonomy-rights that our forebears identified in the Declaration of Independence and saw fit to guarantee to us in the Constitution-pursuant to the grant of some sort of constitutional authority of its own, but of course there is no such grant. Instead, government, as guided by a moralistic and often intolerant majority, has proceeded to systematically strangle many of our basic constitutionally-guaranteed private freedoms, thus turning our American sea of liberty into a sea of government authority. ${ }^{184}$

Many say this is acceptable. We are, after all, committed monists say, ${ }^{185}$ a nation founded on democratic principles - the idea is that government obtains the consent of the governed ${ }^{186}$ through an election process in which citizens elect fellow citizens, who presumably then represent the interests of all in the process of lawmaking. ${ }^{187}$ If it is the majority's will in the course of its legitimate policymaking on matters involving government taxing and spending, etc., also to impose limits on the behavior and free will of individuals, then so be it. Those who disagree with the policy decisions of the elected representatives have recourse every few years at the polling station, so dissenters among the oppressed minority should stop whining and live

184. See supra note 79.

185. See supra note 28 .

186. It is said that obtaining "consent of the governed" is a necessary, basic element for legitimate government: "[C]oherent, stable-and morally supportable-government is possible only on the basis of consent, and ... the secret of consent is the sense of common venture fostered by institutions that reflect and represent us and that we can call to account." ALEXANDER BICKEL, THE LEAST DANGEROUS BRANCH 20 (Yale 2d ed. 1986) (1962) (discussing Judge Learned Hand's favoring of democratic institutions and principles over the counter-majoritarianism inherent in America's practice of broad judicial review). But see BARNETT, supra note 42 for the proposition that true "consent of the governed" is impossible to achieve.

187. Most assuredly, elections are imperfect proxies for the governed and their interests. As Professor Bickel surmised,

It may be, as Professor Robert A. Dahl has written, that elections themselves, and the political competition that renders them meaningful, "do not make for government by majorities in any very significant way," for they do not establish a great many policy preferences. However, "they are crucial devices for controlling leaders."

BICKEL, supra note 186 at 18-19 (quoting DAHL, ROBERT A., A PREFACE TO DEMOCRATIC THEORY 125, 132 (1956). Or, as stated by Judge Hand, "Of course I know how illusory would be the belief that my vote determined anything; but nevertheless when I go to the polls I have a satisfaction in the sense that we are all engaged in a common venture." Id. (quoting LEARNED HAND, THE BILL OF RIGHTS 73-74 (1958)). 
within the limits that have been imposed upon their freedom.

Of course to the rights foundationalist ${ }^{188}$ this vision is unacceptable in a nation founded on principles of freedom and individual liberty. Government, whether guided by democratically-elected majorities or not, simply lacks authority to deprive We the People of natural rights of freedom of autonomy on matters of private concern - rights, after all, that had been recognized and guaranteed in the nation's founding documents-except under the most extreme circumstances. Such rigorous protection of rights assuredly is not the status quo in America.

So, America is at a crossroads. Will Americans continue along their current path of complacency and allow an ever-greater number of government prohibitions and restrictions on matters of natural private concern? Or will they say "Enough!" and take necessary steps to put government back in its proper place?

If there is to be any hope for improvement, law and policy-makers must be reminded, and must begin to give effect once again (mostly by simply refraining from acting), to the core political theory memorialized in the Declaration and Constitution that Americans should be "protect[ed] in their beliefs, their thoughts, their emotions and their sensations ... [and their] right to be let alone - the most comprehensive of rights and the right most valued by civilized man ... [and that] to protect that right, every unjustifiable intrusion by the government upon the privacy of the individual, whatever the means employed, must be deemed a violation." "189 Courts, moreover, through the assertive exercise of its indispensable power of judicial review, ${ }^{190}$ must hold law and

188. See supra note 28.

189. Olmstead v. United States, 277 U.S. 438, 478 (1928) (Brandeis, J., dissenting).

190. The doctrine of judicial review is regarded by some as nothing short of America's greatest contribution to constitutional theory. As Professor Bickel puts it,

Marbury v. Madison ... exerts an enormous magnetic pull. It is, after all, a great historic event, a famous victory; and it constitutes, even more than victories won by arms, one of the foundation stones of the Republic. It is hallowed. It is revered. If it had a physical presence, like the Alamo or Gettysburg, it would be a tourist attraction; and the truth is that it very nearly does have and very nearly is. At any rate, most of us share, as Thayer said, in the moral approval of the lines.

BICKEL, supra note 186173 , at 74 . Commentators are not unanimous in their praise, however: "[N]othing ... can alter the essential reality that judicial review is a deviant institution in the American democracy." Id. at 18 . Judge Learned Hand, for one, favored democratic institutions and principles over the counter-majoritarianism inherent in America's practice of broad judicial review: "It would be most irksome to be ruled by a bevy of Platonic Guardians, even if I knew how to choose them, which I assuredly do not. If they were in charge, I should miss the stimulus of living in a society where I have, at least theoretically, some part in the direction 
policy-makers strictly accountable to upholding the concepts of "liberty" and "property" as they were understood in all of their broad scope by the founding and Reconstruction generations, who believed that the right of individual freedom of autonomy is guaranteed squarely within these expansive terms. ${ }^{191}$

Moreover, the Supreme Court should continue along the path upon which it embarked in 1999 in Saenz $v$. Roe, and allow the Fourteenth Amendment privileges or immunities clause to fulfill its originally-intended and most noble purpose of righting some of the wrongs of the original Constitution ${ }^{192}$ and of providing more complete protection for the individual natural rights of all Americans. The historical record convincingly demonstrates what the Thirty-Ninth Congress intended for the clause, ${ }^{193}$ and as is becom-

of public affairs." LEARNED HAND, THE BILL OF RIGHTS 73 (1958). Thayer suggested, moreover, over 100 years ago, that the very intrusiveness of judicial review cannot help but lead to a self-fulfilling weakening of the legislature:

The legislatures are growing accustomed to this distrust and more and more readily inclined to justify it, and to shed the considerations of constitutional restraints ... turning that subject over to the courts. ... The people, all this while, become careless as to whom they send to the legislature; too often they cheerfully vote for men whom they would not trust with an important private affair, and when these unfit persons are found to pass foolish and bad laws, and the courts step in and disregard them, the people are glad that these few wiser gentlemen on the bench are so ready to protect them against their more immediate representatives.... The tendency of a common and easy resort to this great function, now lamentably too common, is to dwarf the political capacity of the people, and to deaden its sense of moral responsibility.

BICKEL, supra note 186, at 21-22 (quoting J. B. THAYER, JOHN MARSHALL 103-04, 106-07 (1901)).

191. See supra notes $48-52$ and accompanying text.

192. As Professor Rhonda Magee Andrews writes,

the endorsement of slavery in the Constitution... made every American who wished to love his or her country complicit in the endorsement of white superiority at its origination. At its very founding, then, our country broke the spirit of its highest aspirations and made a mockery of American civilization and humanity itself. DuBois summarized the implications this way:

"With the faith of the nation broken at the very outset, the system of slavery untouched, and twenty years respite given to the slave-trade to feed and foster it, there began, with 1787 . . . a moral, political, and economic monstrosity, which makes the history of our dealing with slavery ... so discreditable to a great people"... [The Reconstruction Amendments] would be seen as giving back what the slavery compromises took away: they were to mend the country's spirit ... [to] be interpreted as embodying the spiritual and moral principles undermined by the original Constitution.

Magee Andrews, supra note 179 at 496 (quoting W.E.B. DUBOIS, THE SUPPRESSION OF THE AFRICAN SLAVE-TRADE TO THE UNITED STATES OF AMERICA 1638-1810 198 (1896)). 38.

193. See supra notes $169-70$ and accompanying text. See also LAWRENCE, supra note 
ing increasingly clear with the passage of time the Supreme Court was just plain wrong in 1873 to deny the privileges or immunities clause its proper place in the constitutional firmament. The mistake that was the Slaughterhouses Cases should finally be corrected and put to rest.

As meaningful and positive as these steps would be, they would still be second-best when compared to the ideal, though improbable, ${ }^{194}$ step of a constitutional amendment explicitly guaranteeing that the right of freedom of autonomy on matters of natural private concern-a right contemplated in the Declaration of Independence and guaranteed in the Constitution-shall not be abridged by either federal or state government. ${ }^{195}$ An amendment would be best because the fact is that currently the judiciary, dispersed as it is throughout the fifty separate states and thirteen federal circuits, is woefully inconsistent in its decision-making on freedom of autonomy matters, so an individual's protection from government infringement is highly dependent on the random matter of where the individual lives. ${ }^{196}$ Moreover, even though the historical record does express the framers' original intent to include the right of freedom of autonomy within the terms "liberty" and "property" and "privileges or immunities," 197 admittedly those terms are sufficiently ambiguous as to be subject to misunderstanding or misinterpretation by the courts - and so they have been. ${ }^{198}$ The courts, by failing over

194. See supra note 39.

195. The amendment might read, tracking closely the First Amendment's protection of speech, "Neither Congress nor any State shall make or enforce any law abridging the freedom of individual autonomy on matters of natural private concern." The shift in presumption would resolve close questions against the government, much like the analogous First Amendment.

196. Judicial opinions themselves are all over the board on matters of individual freedom. It is not at all unusual, for example, that the newspaper in the course of any few days will report on how a court in one jurisdiction has upheld a particular privacy right, while another has struck it down. For example, on one recent day the New York Times had the following headlines on the very same front page regarding court opinions on same-sex marriage: "Court Upholds Federal Restrictions on Gay Marriage" (describing an opinion of the federal court of appeals); and "New York Gay Marriage Allowed." (reporting an opinion of the state of New York's highest court). N.Y. TIMES, Feb. 4, 2005 at Al. More recently on this issue, a California court upheld gay marriage in California. Judge strikes down California gay marriage ban, MSNBC, Mar. 14, 2005, http://www.msnbc.msn.com/id/7182628/.

197. See supra notes 47-53, 166-169.

198. Some of the judiciary's cautious response is understandable - courts, under separation of powers principles, give deference to coequal branches of government and are properly hesitant to strike down their actions except in clear cases. As Jed Rubenfeld writes,

constitutionalism as democracy is very broadly opposed to judge-made "fundamental rights" not derivable from any of the nation's written constitutional commitments. Little room for extra-textual constitutional law exists on the model of writing. But not no room. There are, at the extreme limits of what a democratic government might try to do with or to its citizens, certain unwritten laws of written constitutionalism, and a right of privacy is among them. 
time to give those words their full intended effect, have effectually institutionalized (but still not memorialized) their lesser meanings through operation of the common law and the doctrine of stare decisis. ${ }^{199}$ The Slaughterhouse Cases' effect on the privileges or immunities clause is the classic case in point, where an erroneous interpretation of a constitutional provision by the Court effectively put the provision out of play for (at least) the following 130 -plus years. ${ }^{200}$

In short, a constitutional amendment would solve these problems by providing much-needed guidance to the judiciary (both state and federal) in its exercise of its judicial review function, and also to the

Rubenfeld, supra note 70 at 223. See supra text accompanying note 70 for Rubenfeld's discussion of anti-totalitarian right to privacy.

199. The Supreme Court's privacy cases:

merely reemphasize the embarrassing sense of artifice, of post-hoc rationalization, that has accompanied the right of privacy since the Supreme Court first discerned it in the "penumbras" and "emanations" of the Bill of Rights... . Every time such a right is posited by a judge (or anyone else), there has to be some extra-textual account of its constitutional status - some extra-textual account of why this particular right counts, even though unwritten, as a constitutional right. And such an account has to answer to all the demands of legitimacy imposed by constitutionalism as democracy when unelected judges render constitutional decisions for the nation.

RUBENFELD, supra note 70, at 222-23.

200. When this "most extraordinarily powerful court of law the world has ever known," BICKEL, supra note 186, at 1 , does slip up - and it does all-too-frequently - the effects can be devastating to the individual rights of millions for many years or even decades. For example, Dred Scott v. Sandford, 60 U.S. (19 How.) 393 (1856) (holding that slaves were considered as "property," not "citizens," under the Constitution) played a major role in precipitating the Civil War; Plessy v. Ferguson, 163 U.S. 537 (1896) (holding that majority-driven "separate but equal" laws in the states did not violate the equal protection rights of the black racial minority) authorized Jim Crow discrimination of racial minorities for another sixty years; and Korematsu v. United States, 323 U.S. 214 (1944) allowed the forced relocation of many thousands of innocent U.S. citizens of Japanese-American descent into internment camps during World War II. Bush v. Gore, 531 U.S. 98 (2000), with its implausible equal protection chimera barely masking an underlying political cast, deeply wounded the prestige of the U.S. Supreme Court, and exposes an Achilles heel in our constitutional system of checks and balances. Specifically, the integrity of judicial review relies ultimately on the opinions of nine individuals who have reached that exalted station in no small part because [largely as a result] of their superior ability to negotiate the politics of judicial appointment. As long as the appointment process works well enough to maintain a majority of competent Justices who are truly independent and not ideologically or politically driven toward a particular viewpoint, we're mostly okay, but with the appointment of one or more additional ideologically-driven hard-right conservative Justices to take the place of retiring Justices in the next several years, this Court has the potential to hand down a case that may be judged by history in class together with the earlier three in terms of violence done to individual liberties. Is there any doubt that the addition of one or two more Justices like Antonin Scalia and Clarence Thomas would make a difference in how the Court decides matters of individual liberty affecting tens of millions of citizens like abortion rights (Roe v. Wade and its progeny, including Casey v. Pennsylvania); gay rights and sexual privacy rights (Lawrence v. Texas) or, for that matter religious freedom? 
other all-too-fallible legislative and executive government institutions entrusted with protecting individual liberties. ${ }^{201}$ The intent in enacting such an amendment would be to offer a scope of protection for matters of private autonomy similar to that guaranteed in the analogous First Amendment's protection of speech, where, in applying the Court's current doctrine, absolute deprivations of freedom of autonomy are upheld only in the most extreme of circumstances, and partial deprivations only if in line with rigid guidelines. As to the latter, the doctrine would apply strict scrutiny if the abridgement of the freedom of autonomy is content-based, and intermediate scrutiny if contentneutral, under which reasonable time, place and manner restrictions may be upheld.

Another advantage of constitutional amendment is that by unambiguously re-claiming rights that We the People had at one time but then lost somewhere along the way to an overbearing government, We adhere firmly to the principle of fidelity to a written Constitution, where any adjustment to our understanding of the Constitution is memorialized through the Article $\mathrm{V}$ amendment process. In effect what We the People are doing is changing the terms of our consent to be governed by adjusting the terms of the "contract"-i.e., the Constitution. If consent of the governed is a necessary element of government legitimacy - and it is, under modern Enlightenment and social contract theory ${ }^{202}$ - there is no other way to alter the terms of that consent than to memorialize the change in the underlying Agreement. ${ }^{203}$ The difference in this

201. On the importance of the guidance provided in a written constitution, it is useful to look back at the original motivations for a constitution at the time of the founding:

The American colonial experience, climaxed by the controversy with England leading to the Revolution, honed American sensitivity to the need for written constitutions that protected rights grounded in the "immutable laws of nature" as well as in the British constitution and colonial charters.... Americans had a novel concept of constitution. The word signified to them a supreme law creating government, limiting it, unalterable by it, and paramount to it. .. "To secure these rights," Thomas Jefferson declared, "governments are instituted among men."

Levy, supra note 2 at 8-9. See also BARNETT, supra note 42 (stating the importance of a constitution to "lock-in" the processes by which those who govern may govern).

202. See supra note 22 and accompanying text.

203. See, e.g., RUBENFELD, supra note 70 , at 223 (writing that "[t]he only constitutional law binding on a democracy that seeks to be the author of its own fundamental legal and political commitments is law that derives from the nation's own acts of memorialization.... [There can be very little] unenumerated constitutional law in [a system of] constitutionalism as democracy. . .). This principle of memorialization thus requires that we must be skeptical of arguments that the constitution may be altered by extra-constitutional factors, "moments," or otherwise. For example, in Professor Bruce Ackerman's theory of a two-track lawmaking system he posits: 
case is that we're in effect "re-memorializing" something that was already memorialized in the first place, but that's okay-if the government didn't get it or understand it the first time, there's nothing wrong with We the People going back and making the point again with more pointed emphasis.

\section{CONCLUSION}

America has fallen far short of the promise made in the Declaration of Independence and Bill of Rights for protecting individual liberties of equality and free choice on matters of natural private concern-rights considered to be natural and virtually inviolable from early pre-Revolutionary years at least into the early decades of the nation. These principles, representing the very core of the revolutionary-era and founding ideology, have been lost over the decades to an overbearing government guided by majorities that are allowed to im-

The lower lawmaking track is intended to register the successful conclusions of pluralist democratic politics-the mix of interest group pressure, regular electioneering, and practical policymaking that characterizes the democratic polity most of the time. The higher lawmaking track, in contrast, is designed with revolutionaries in mind. It ... imposes a rigorous set of institutional tests before allowing a revolutionary movement to transform fundamental political principles.... [(1)] passage of time. Before a revolutionary change is adopted, it should have the sustained support of a substantial majority, not just support at a single moment... [(2) p]opular debate must be given full play before a final decision is reached.... [This is] more than a mechanical vote-count at a referendum. The higher lawmaking system is intended to determine whether a revolutionary initiative has gained the considered support of a self-conscious and deliberate majority.

BRUCE ACKERMAN, LIBERAL REVOLUTION, supra note 18, at 14-15 (1992) (citing BRUCE ACKERMAN, WE THE PEOPLE: FOUNDATIONS (1991)).

This description is well and good, to the extent it is used as the cogent description it is of how politics plays out under our constitutional scheme and results occasionally in a "revolutionary movement to transform political principles" in a policymaking sense. But the moment the theory is extended to support a suggestion that there is some sort of "complex process of 'Publian politics' where 'we the people' become authorized to change the Constitution without ever invoking the procedures laid out in Article V," as suggested by Sanford Levinson on the dust jacket to Ackerman's book, we've gone beyond what is acceptable under our constitutional scheme. See Sanford Levinson, Review IN BRUCE ACKERMAN, WE THE PEOPLE: FOUNDATIONS (back cover dust-jacket) (1991). This theory is pulled out of thin air. It simply cannot be that anyone-We the People or otherwise - can change the Constitution without invoking Article $\mathrm{V}$ if we are truly committed to a system of constitutionalism. To suggest otherwise opens up a Pandora's box of difficult questions about when, for example, we have reached sufficient passage of time and debate to justify "changing" the Constitution. In terms of adherence to basic principles of constitutional fidelity, conceptually this approach is on a par with erstwhile Supreme Court nominee Robert Bork's statement that a particularly disfavored provision of the Constitution (the Ninth Amendment) may be conveniently ignored as if obscured by "an ink-blot on the page." 
pose their beliefs and morality on others.

If the freedom of autonomy is to be revived from its current slumber in modern-day America, Americans must develop a greater understanding of the nature and rich history of this most basic natural right. Greater awareness can lead to a shift in thinking away from the current status quo of government as paternalistic overseer, and back toward the original intent of government subservient to the individual. They may look again to the inspirational words of the Declaration, knowing that from the beginning, our forebears knew it would not be easy. When freedom was on the line, "the colonists knew ... [w] hat would in fact happen [next] ... would be the result . . . of the degree of vigilance and the strength of purpose the people could exert. For they believed ... [t] he preservation of liberty would continue to be what it had been in the past, a bitter struggle with adversity. . .,"204 And so preservation of liberty continues to be what it has been in the past-a bitter struggle with adversity-and only time will tell whether modern-day Americans have what it takes to make the necessary changes to ensure its survival.

204. BAILYN, supra note 5 at 85 . 
